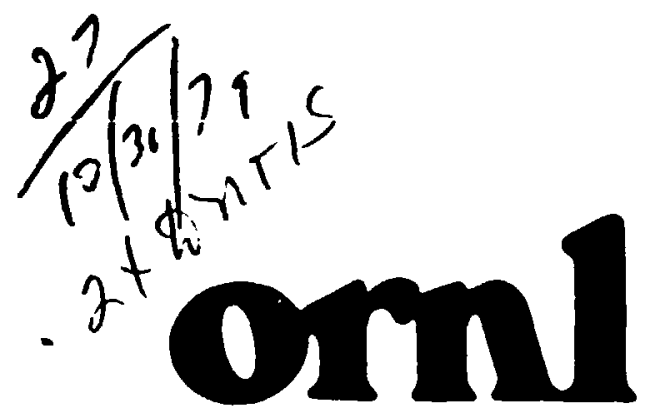

OAK
RIDGE

NATIONAL LABORATORY

UNION

CaRBIDE

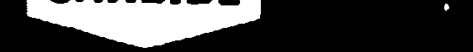

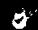

OPERAJED BY

UNION CARBIDE CORPORATION FOR THE UNITEO STATES DFPARTMENT OF ENERGY
ORNL/OIAPA-13

\section{Public Information on Radioactive Waste: A Study of an Emerging Issue}

Lois Martin Bronfman Benson $\mathrm{H}$. Bronfman James L. Regens 


\section{MASTER}

ORNL/OIAPA-13

Contract No. W-7405-eng-26

PUBLIC INFORMATION ON RADIOACTIVE WASTE:

A STUDY OF AN EMERGING ISSUE

\section{By}

Lois Martin Bronfman

Benson H. Bronfman

and

James L. Regens

with the assistance of

R. C. DeVault, K. Harris and C. W. Tevepaugh

Energy Division

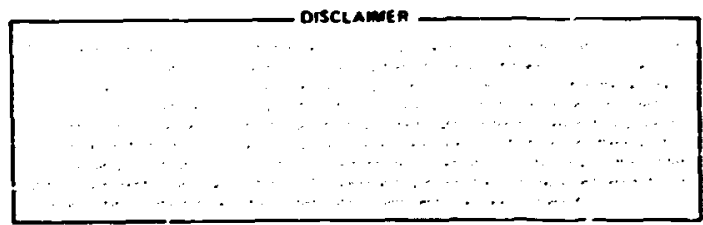

Prepared for

Office of Integrated Assessment and Policy Analysis Health and safety Research Division

Oak Ridge National Laboratory

Date Published - October 1979

OAK RJDGE NATIONAL LABORATORY

Oak Ridge, Tennessee 37830 operated by

UNION CARBIDE CORPORATION

for the

DEPAR'IMENT OF ENERGY 
CONTENTS

Page

LIST OF TABLES ........................ v v

HIGHLIGHTS ......................... vii

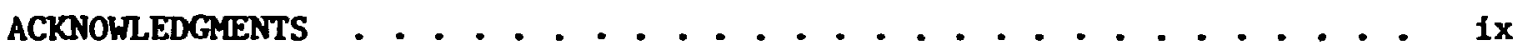

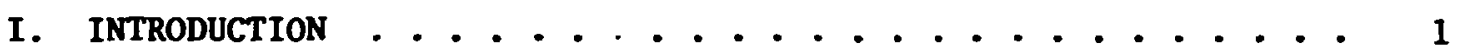

II. SELECTING ARTICLES AND PROCEDURES FOR REVIEW . . . . . . 3

III. THE ERERGENCE OF RADIOACTIVF WASTE AS A PUBLIC ISSUE . . . • 6

IV. THE Radioactive waste POLICy Problem as Reflected IN THE

PRINTED MEDLA . . . . . . . . . . . . . . . . 10

Results .................... 21

The Dominance of Non-Technical Themes . . . . . . . 23

Risk Themes .................. 23

Institutional Themes ................ 24

Socio/Economic and Ethical Themes . . . . . . . . 24

V. PUBLIC INFORMATION OVER TIME ON THE TOPIC OF RADIOACTIVE

WASTE . . . . . . . . . . . . . . . . . . 26

Results ................... 26

Nc:-ional Press .............. 26

General Scientific ............ 32

Nuclear Scientific ............. 32

Environmental ............ 33

The Nuclear Industry/Utility Sources ....... 34

The Significance of Changes in the Content of

Information ............... 34

VI. COMPARISON BETWEEN SOURCES IN THE CONTENT INFORMATION ON

RADIOACTIVE WASTE . . . . . . . . . . . . . . . . . 37

VII. A WOTE ON THE QUALITY OF TECHNICAL INFORMATION AVALLABLE

TO THE PUblic .................... 41

VIII. FINAL OBSERVATIONS .................. . . 44

REFERENCES .......................... 4 48 


\section{LIST OF TABLES}

Table $\quad \underline{\text { Page }}$

1 Number of articles by year and source .......... 7

2 Theme categories .................. 11

3 Percentage distribution of themes by source, 1973-1978 . . . 22

4 Emergence of themes over time: National press . . . . . 27

5 Emergence of themes over time: General Scientific . . . . 28

6 Emergence of themes over time: Nuclear Scientific . . . . 29

7 Emergence of themes over time: Environmental ....... 30

8 Emergence of themes over time: Nuclear Industry/Utility . . 31

9 Emergence of themes over time/all sources . . . . . . 35

10 Radioactive waste defined by source . . . . . . . . 42 
HIGHLIGHTS

PUBLIC INFORMATION ON RADIOACTIVE WASTE:

A STUDY OF AN EMERGING ISSUE

The purpose of tinis study is to provide information to decisionmakers which will assist in the task of formulating policies for radioactive waste management so that the policies address the concerns and interests of the public. Through an analysis of information provided in the printed media en the topic of radioactive waste, the study analyzes the emergence of radioactive waste as a public issue in the press. Over eight hundred articles printed in both specialized and non-specialized sources from 1973 to 1978 have been content-analyzed in order to describe how the problem of radioactive waste is defined and what dimensions of the problems are recelving attention. Data on the content of information are differentiated by source of information (i.e., national press; general scientific press; industry/utility press; nuclear scientific press; environmental press; and loca! press) and over time. Major findings include:

1. In the s:x year period between 1973 and 1978 there was a substantial increase in the amount of information on the todic of radioactive waste availabie to the public through a variety of popular and speciallzed media sources. The increage in information coincides with documented public concern with the problem of radioactive waste.

2. Discussions of radiosctive waste have focused for all sources more frequently on themes not directly related to the technical problems of radioactive weste storage or isolation.

3. A substantial amount of the information available to a variety of segments of the public is composed of discussions of real or perceived risk related to the existence of waste or to methods of disposing of $i t$.

4. In addition to risk, a substantial proportion of the discussions deal with institutional themes.

5. Over time, the total amount of information on most dimensions of the radioactive waste problem has increased substantially. Institutional themes have gair.ed relative to other fissues over th? three time periods.

t. Information sources do vary in the relative attention which each gives to dimensions of the radioactive waste problem. Overall, the broad patterns are quite similar, however.

7. Nitional and local press sources infrequently specify the form of waste being discussad thus providing evidence thet the quatity of technical information avallable to some members of the public is very low. 


\section{ACKONONLEDGMENTS}

The authors wish to thank those who helpfully commented on earlier drafts of this document. Individuals who were particularly helpful include Robert Cameron Mitchell (Resources for the Future); Paul Slovic (Decision Research Inc.); Tom Wilbanks, Sam A. Carnes, Denny Parzyck, Ken Cowser and Richard Davis (ORN).

Special thanks go to Ruth Friar, who typed more than the requisite number of drafts and revisions for a document of this nature, and Emily Copenhaver for her consistently superior administrative support. 


\section{I. iNTRODUCTION}

The problem of radioactive waste management has become increasingly apparent to government offictals and to the broad public. The President's anncunced concern with the radioactive waste problem, 1 coupled with the creation of an Interagency Review Team to study various policy alternatives, higliights the importance of this issue on the formal deciston making agenda.

The renewed efforts to find realistic and practical solutions to the radioactive waste problew are partially in recyonse to public concern and/ or opposition to existing policies. New policies which are foraulated are expected to meet these concerns and to promote public acceptance. ${ }^{3}$ The purpose of this study is to provide information which will assist in the task of discerning public concern. Through an analysis of information provided in the printed media on the topic of radioactive waste, the study describes the emergence of radioactive waste as a public issue in the press. Eight hundred twenty-six articles printed in hoth specialized and nonspectalized sources during the period 1973-1978 were reviewed in order to describe how the problem of radioactive waste is being defined and what dimensions of the problems are receiving attention.

Our attention is focused on the media because it is an important factor which draws the attention of the public to policy problems and contributes to the emergence of an issue on the public agenda where, in the view of a sizeable proportion of the public, it requires governmental action. 4 Moreover, the treatment which the media gives to the problem is an important factor structuring public opinion on the policy problem. ${ }^{5}$ Thus, while the study is not a direct measure of public opfinion, it does suggest how the radioactive waste problem will be defined and what dimensions of the problem will emerge as issues for the public. As such, the study provides necessary groundwork for more direct measures of public opinion. In addition, to the extent that the media documents public debates on any policy issue, the study describes the content of the debates over radioactive waste management.

The method used to describe the content of the information avallable In a variety of press sources is content analysis. The bulk ${ }^{6}$ of research on public opinion and the effect of media coverage postulates that the content of Information focuses the attention of the public on certain 

dimensions of the problem but does not determine on what side of the various issues that are raised an individual might take a position. 7 For this reason, in our analyses we have reviewed the content of information on radioactive waste looking for broader themes, rather than narrow issues, which define the parameters of the problem. In addition, in analyzing information in the printed media, we focused on different information sources. Different presses exist which supply information to different groups within the broader attentive public. For example, the Atomic Industrial Forum's newsletter, INFO, with its subtitle "Public Acceptance of Nuclear Power," reaches quite a different audience and has a different purpose than the Los Angeles Times or the New York Times. Because of these differences, we have chosen to distinguish between different information sources in much the same manner that the public opinion 1iterature distinguishes between different "publics." 8

The sources in this study are differentiated primarily by the different audiences the publications right represent in the nuclear power controversy. 9 The major categories chosen were: national press; generai scientific press; nuclear scientific press; nuclear industry/utility press; environmental press; and local press (for Louisiana and Michigan). Government sources were excluded from our analysis because they are the basis for background information in many public sources and they primarily define what decision makers perceive as the policy problem. Our concern is not to define official policy or official concerns. Rather, our focus is on one means, public information sources, by which the policy problems are interpreted for the public. 


\section{SELECTING ARTICLES AND PROCEDURES FOR REVIEW}

The search for articles on radioactive waste involved several steps.

For discussions of radioactive waste in popular sources, the Reader's Guide to Periodical Literature and the New York Times Data Bank were consulted. All articles mentioning radioactive waste and indexed for the period January 1973 to June 1978 were included in the bibliography and content analyzed. 10 To search out articles in the more specialized information sources (e.g., Nuciear News, Utilities Fortnightly, Critical Mass), the authors relied on the Central Research Library and the Energy and Environmental Response Center Library at Oak Ridge National Laboratory as well as the personal libraries of some of ORNL's staff. A spectrum of journals and newsletters representing different editorial policies from each specialized source was sought. For example, Nuclear News, Nucleonics Weekly, and The Bulletin of Atomic Scientists were included in the nuclear scientific category. Likewise Nuclear Opponents and Environmental Action were included In the environmental category. Each journal selected was searched for radioactive waste articles appearing during the 1973-1978 period, and all articles found were analyzed. In addition, the formez Office of Waste Isolation, Union Carbide Corporation-Nuclear Division (UCC-ND), made avaflable its extensive newspaper clippings from local newspapers in the States in which research was planned to determine the suftability of selected sites for hosting a radioactive waste facility. These clippings files were extensive and included articles from a variety of local newspapers in each state.

The material was then organized into broad categories based on the source of information. These categories are (1) National Press; (2) General Scientific sources; (3) Nuclear Scientific sources; (4) Environmental sources; (5) Nuclear Industry/Utility sources; and (6) Local Press. A complete listing of the sources which make up each category is contained In Radioxative Waste: 'A Bibliography of Printed Media Sources, 1973-1978, ORNL/OEPA-14 (March 1979).

The national press category Included among others Newsweek, Time, Readers Digest, and major metropolitan newspapers. These sources most likely reach and are directed at a large portion of the general attentive public, although certainly the sclentific public and other spectalized 
groups have access to them. We assume, however, that for some individuals the only information which they have on radioactive waste management comes from these sources. There is no reason to assume that these information sources have a pro- or anti-nuclear bias. The audience to these sources is quite broad. The New York Times has a circulation of $1,008,995$ and the Los Angeles Times 803,123. 11

Articles from such sources as Science, Scientific American and Science Digest contributed to the general scientific category. These information sources reach a specialized audience. They are probably read by a broad spectrum of the scientific community. The sources carry articles and editorials on a variety of academic and policy issues of interest to their readers. Access to this information is more restricted than for the national press: Science, for example, comes primarily to members of the American Association for the Advancement of Science. The current membership however, totals $149,557.12$

Articles from journals which are read primarily by members of the nuclear scientific comunity were also grouped together into the nuclear scientific category. These journals, we assume, reflect the interest and concerns of those involved directly in research or in decision-making on nuclear power. Included in the selection were such fournals as Nuclear News, Nucleonics Weekly, and the Bulletin of Atomic Scientists. As might be expected, these sources provide many of the facts and figures on rhich a case for or against nuclear power can be made. Circulation of Nuclear News is $13,343.13$

The nuclear industry/utility sources included articles and news items disseminated by the Atomic Industrial Forum, the major lobbying group for the nuclear industry; some advertisements and public relations documents developed by industry spokesmen for public use; and articles which appeared ir. such Journals as Electric Perspective's, Aware, and Utilities Fortnightly. INFO, published by the Atomic Industrial Forum, is a publication whose function is to provide information to its members about the status of the industry in the public's view as well as its status with respect to government support and regulation. It is probably the most comprehensive summary source of information on the opposition to nuclear power since it provides 
names, dates, places, strategies and reviews speeches, books, articles, and media coverage of nuclear power issues.

Environmental sources included such publications as Critical Mass, Environment, Nuclear Opponents, and Nuclear Blowdown, a Friends of the Earth Publication. These publications reach a specialized audience whose concern with the impacts of radioactive waste management most 1ikely reflects a broader concern with environmental protection. As might be expected, the reviewed sources presented positions which were in opposition to nuclear power for electrical generation. Available estimates of the size of the publics for these publications range from $9,000^{14}$ for Critical Mass to $22,000^{15}$ for Friends of the Earth. The local press category included articles from Louisiana and Michigan (e.g., The Saginow News, the Detroit Free Press, the Minton Press Herald, and the Shreveport Times).

Having collected ti.e bibliography, summaries of each of the articles were prepared by two research assistants who were directed to record major issues or themes in each discussion as well as to code additional information as to the type of article, the year published, and the form of radioactive waste discussed. The index of agreement ${ }^{16}$ for sumarizing issues was 0.86 , and 0.80 for the question of how waste is defiried. Using these summaries, the authors developed fifteen thematic categories which permitted classification of the different themes or issues across sources. The summary data was then coded into the fifteen thematic categories. One thossand six-hundred themes were coded for the 826 articles. To determine the reliability of the final coding process and to recapture some of the details lost in the initial analysis, an author who was not originally Involved in the coding worked back from a samplt of unlabeled but similarly numbered coded themes to the summarizing statemrnts. This process resulted in the redefinition of certain issue categortes, even though great consistency was found in the information included in earh category. Review of the coded thematic categories also resulted in the further organization of the fifteen thematic categories into four broader categories which reflect underlying dimenstons of the polfcy discussion. For a detalled discussion of the major thematic categories see Scct. IV. 
III. THE EMERGENCE OF RADIOACTIVE HASTE AS A PUBLIC ISSUE

In the six yea: period between 1973 and 1978 there was a substantial increase in the amount of information on the topic of radioactive waste available to the public through a variety of popular and special interest press sources (see Table 1). This increase in information coincides with documerted public concern with the problem of radioactive wastes and as such lends support to the proposition that the media contributes to the setting of the public agenda on policy issues. ${ }^{17}$ Although, generally, more articles appeared in nuclear scientific sources, the publicity on a variety of dimensions of the problem appears to be diffused across information sources. This finding supports Schoenfeld's thesis that the agenda-setting function of the media - ac least for environmental issues - is diffused and inclusive of the mass media. 18

While the increase in press coverage from 1973 to 1978 is apparent, discussions of radioactive waste did not emerge for the first time in either the popular or the specialized presses during this period. A review of only those articles included in the Reader's Guide to Periodic Literature from 1945 to 1973 indicates that radioactive waste first gained some media attention in more popular sources after the dropping of the nuclear bonb in Japan. In 1947-49, there were three articles mentioned in the Guide. This attention was increased substantially from 1955 to 1963 during the polfcy debates over atmospheric testing. (Approximately 19 articles appeared in the Reader's Guide for 1955-57 and 30 articles appeared in the 1959-61 period.) The problem of nuclear fallouc and of the storage of other military wastes were the foci of attention. It was in 1957, too, that the National Academy of Sciences, through a special report, drew attention to the radioactive waste problem. 19 From 1963 to 1970, however, radioac :Ive waste received little attention in press sources (approximately four articles were noted in the Guide in that period). As a consequence, the period which we reviewed marks, we think, the re-emergence of the issue in the media.

There are a number of related explanations for its re-emergence. By the 1970 's, the variety of national 1ssues which dominated the press in the 60's had diminished (e.g., Viet Nam and civil rights), and the opportunities for discussion of other policy issues increased. One of the policy issues to 
Table 1. Number of articles by year and source

\begin{tabular}{lcccr}
\hline & $1973-74$ & $1975-76$ & $1977-78$ & Total \\
\hline & & & & \\
National Press & 12 & 33 & 77 & 122 \\
General Scientific & 13 & 16 & 41 & 70 \\
Nuclear Scientific & 40 & 86 & 92 & 218 \\
Nuclear Industry/ & & & & \\
$\quad$ Uitility & 7 & 33 & 39 & 79 \\
Environmental & 11 & 37 & 54 & 102 \\
Local Press & 0 & 32 & 203 & 235 \\
$\quad$ Local & 83 & 237 & 506 & 826 \\
\hline
\end{tabular}


recelve more attention was the nation's commitment to the commercial nuclear power industry. When radioactive waste was identified by key participants in the emerging public debate as a major problem which could impede commercial nuclear power development, the issue became increasingly newsworthy. 20 Thus, as discussions and controversy over nuclear power intensified, more articles on radioactive waste appeared.

The growth of public information has also coincided with increased policy and rescarch activity in radioactive waste magement. This activity was necessitated not only by the existence of radioactive waste from our military commitment to nuclear weapons, but by the blossoming of the commercial nuclear reactor industry and the plans to reprocess spent fuel from this industry. In Decemiver of 1970 there were 19 operating reactors. Five years later there were 54 operating reactors. 21 By 1974 , commercial radioactive wasle was a reali: $y$. Because the industry was commercial and because it was also subject to increasing governmental regulations, the attention given to management and regulation was subject to public scrutiny and media coverage. This right of public scrutiny is in sharp conirast to the conditions under which milicary and experimental reactor work is handled.

The commitment which the Federal government made in the late 60's and early 70 's to public involvement in policy formation also contributed to the emergence of the issue in the media. The actions which the government took to find a suitable site for a radioactive waste repositoly resulted, ior example, in considerable interaction between Federal representatives, state, and in some instances, the local pubilcs. This interaction brought local public attention to radioactive waste policy efforts and contributed to the emergence of the issue in the national press.

Finally, atcention to radioactive waste problems was reinforced by growing public attention to a variety of environmental issues and to the growth of the environmental movement. ${ }^{22}$ As another form of possible pollution, radioactive waste had the interest and attention of the environmental movement and its supforters. This attention resulted in increased publicity. W11 the flow of information persist? Anthony Downs postulates that there exists a five-stage issue attention cycle for environmental issues. ${ }^{23}$ stage One, or the pre-problem stage, prevalls "when some highly undesirable 
social condition exists, but has not yet captured much public attention, even though somp experts of interest groups maj already be alarmed hy it." The radioactive waste issue is past this stage. In Stage Two, as a result of :some dramatic events, the public becomes aware of and alarmed by the probiem. This awareness is facilitated by increased media attention. In this stage there is general acceptance of the notion that the problen can be solved. Stage Three occurs when the public gradually realizes that there is sme cost to "solving" the problem. Stage Four occurs then there is a gradual decline in public interest as a result of individuals becoming bored or ovel wheimed by the difficilies of solving the problem. In the final stage, or post-problem stage, the issue has been replaced at the center of public concern and "moves into prolonged limbo - a twilight realm of lesser attention or spasmodic recurrences of interest."

Assuming that such a cycle exists, then the data indicate that the radioactive waste issue, as it is addressed in the 1970's, is still on the "up" side of the cycle. Moreover, because the waste problem is periodically redefined or refocused as it was after, for examole, the decision to postpone reprocessing, we suspect that media attention will persist for quite some time, or until there is resolution of mafor radioactive waste issues such as the storage of high level commerclal waste. 
IV. THE RADIOACTIVE WASTE POLICY PROBLEM ASS REFLECTED IN THE PRINTED MEDIA

of what importance is the increase in media attention? There are 3 number of possible effects. Certainly increased attention expands the audience to any conflicts whici may arise over the issue, and in some instances may mobilize individuals to participate in these conflicts. Media attention may in addition create greate: opposition to efforts to implement the technological dimensions of the policy. Finally, and this is the effect in wifch we are primarily interested: attention by the media to a specific issue not only tends to place the issue on the public's agenda for consideration but it also tends to structure how the problem is defined by recipients of that information. In this case, we assume that the attention which the different presses focus on the variety of issues and themes defines for the readers of these presses the problem of radioactive waste.

In this study 15 separate theme categories were Identified: Existing disposal technology; Technology RD\&D; Management; State and local government policies and decisions; Federal policies and decisions; Intergovernmental conflicts; International policies or issues; Procedures for formulating policies; Transportation; Theft/sabotage/security; Hzalth hazards; Volume of waste/existence of waste; Economic costs of waste management; Public reaction; and Ethical issues. These categories were in turn organized into four broad categories which represented major underlying dimensions of the policy discussion: Technical; Institutional; Risk; and Social/Economic/Ethical. Table 2 presents the organization of these dimensions; describes the 15 thematic categories, notes what information was included in each thematic category and provides a cample of themes from the different press sources. ${ }^{24}$ (See Section II for discussion of how thenes were derived.)

The technical dimension included two thematic categories. Information which describes the existing technology for waste disposal as well as potential technical options is one category. Themes of tl.s type included the technical merfts and problems associated with existing waste disposal technologies. A dominant approach was that of geological disposal, and more specifically, disposal in salt deposits. Disposal in cceans was also mentioned and it war not unusual to find descriptlons of technologies operating In forelgn countries. Some questions were rafsed as to whether any of 
Table 2. Theme categorles

\begin{tabular}{|c|c|c|}
\hline Categories & Defintition & Press Summary Examplea \\
\hline \multicolumn{3}{|l|}{ 1. Technical issues } \\
\hline $\begin{array}{l}\text { 1. Existing disposal cechnology } \\
\text { and/or technical options for } \\
\text { radioactive waste disposal }\end{array}$ & $\begin{array}{l}\text { Discussions of the technical merits and prob- } \\
\text { lems associated vith existing waste disposal } \\
\text { techniques and proposed disposal options }\end{array}$ & 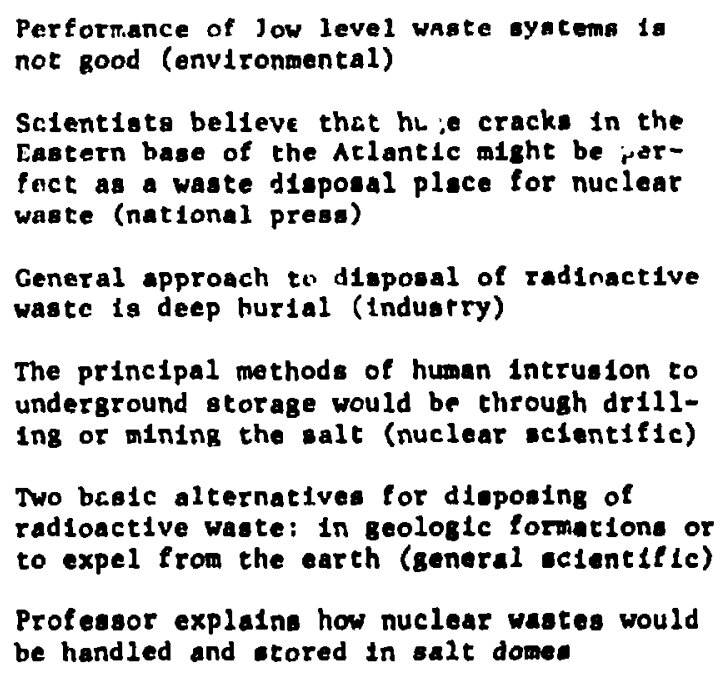 \\
\hline 2. Technology RD \& D & $\begin{array}{l}\text { D1scussions of experimental results on new } \\
\text { technologies and the need for research }\end{array}$ & 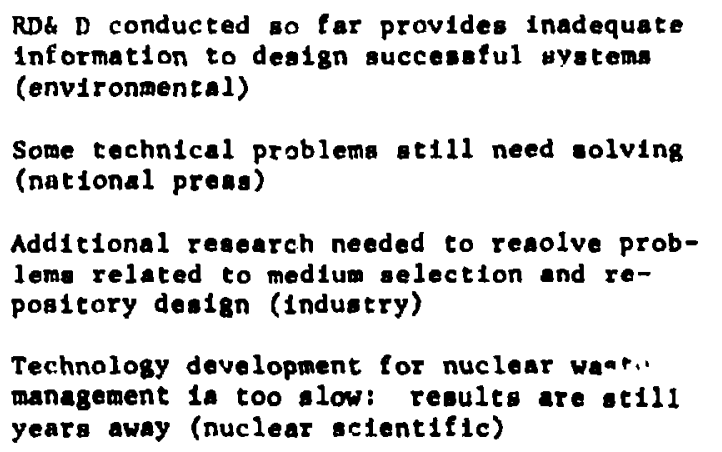 \\
\hline
\end{tabular}


Table 2. Theme Categorles (continued)

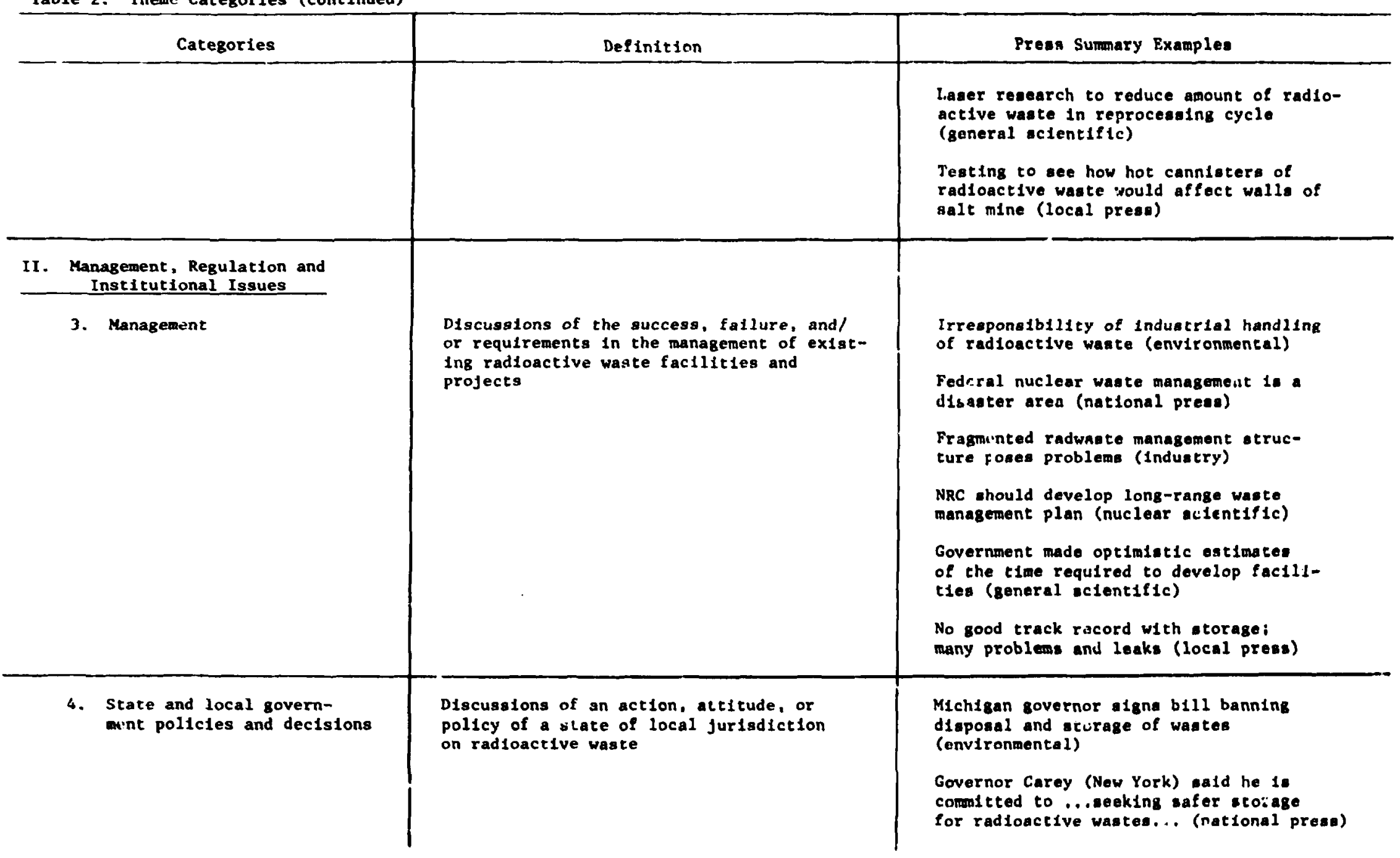




\begin{tabular}{|c|c|c|}
\hline Cacegories & Definition & Prees Summary Examples \\
\hline & & 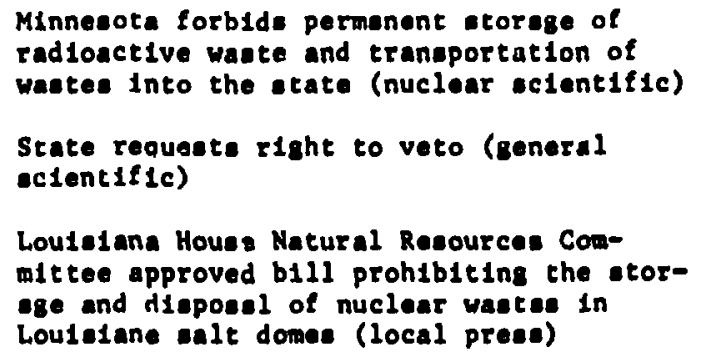 \\
\hline 5. Taderal pollcles and decisions & $\begin{array}{l}\text { Diecuselons of an action, deciaton, or } \\
\text { pollcy of the Federal government on } \\
\text { radioact lve waste }\end{array}$ & 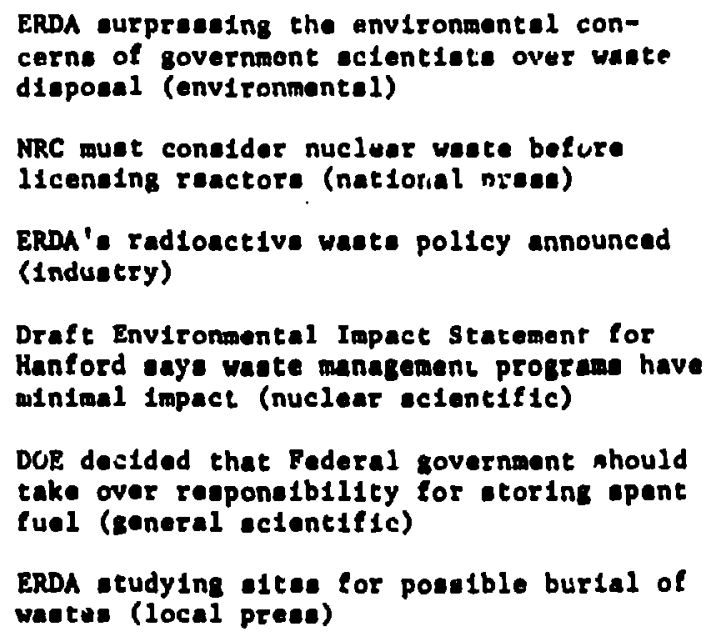 \\
\hline 6. Intergovernmental conflict & $\begin{array}{l}\text { Discuasiona of exlating or potential conflict } \\
\text { among vartous levela of government or between } \\
\text { varlous branches of government at the Federal } \\
\text { level }\end{array}$ & $\begin{array}{l}\text { AEc may otore wastes where it has substan- } \\
\text { t1al payrolle such ae Novada, Idaho, or } \\
\text { Washington (environmental) }\end{array}$ \\
\hline
\end{tabular}


Table 2. Theme categorles (continued)

\begin{tabular}{|c|c|c|}
\hline Categorles & Definit tol. & Preas Surmary Examples \\
\hline & . & 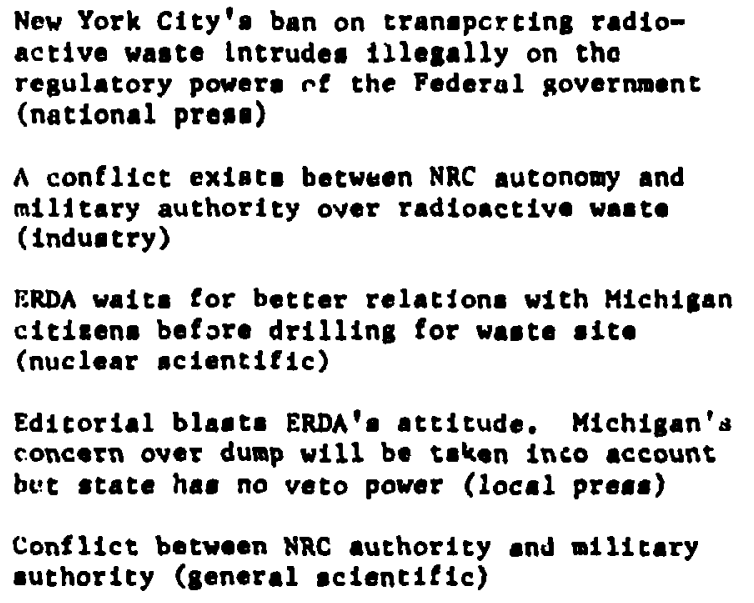 \\
\hline $\begin{array}{l}\text { 7. International policles } \\
\text { or Issues }\end{array}$ & $\begin{array}{l}\text { Reports of effects of International co- } \\
\text { operation in waste management or of pro- } \\
\text { posals to store foreign radioactive waste } \\
\text { In U.S. }\end{array}$ & 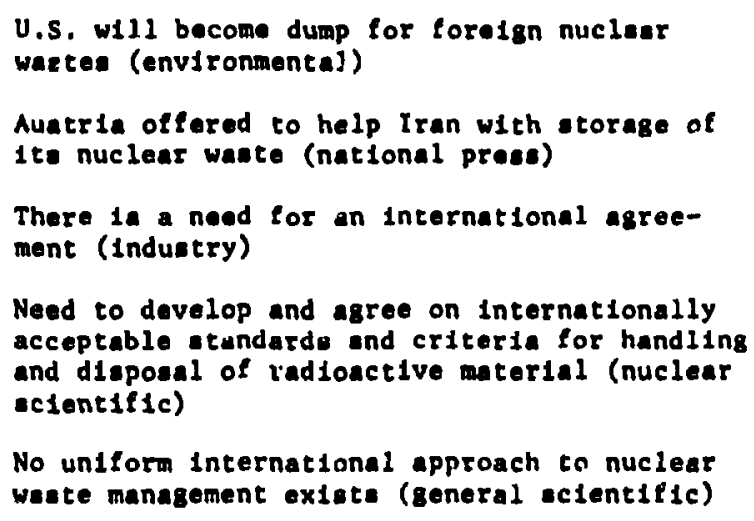 \\
\hline
\end{tabular}


Table 2. Theme categories (continued)

\begin{tabular}{|c|c|c|}
\hline Categories & Definicion & Presa Summary Examples \\
\hline $\begin{array}{l}\text { 8. Procedures for formulating } \\
\text { polictes }\end{array}$ & $\begin{array}{l}\text { Discussions of problem with the procedures } \\
\text { for formulating radioactive waste policy, } \\
\text { particularly procedures for public Involvement }\end{array}$ & 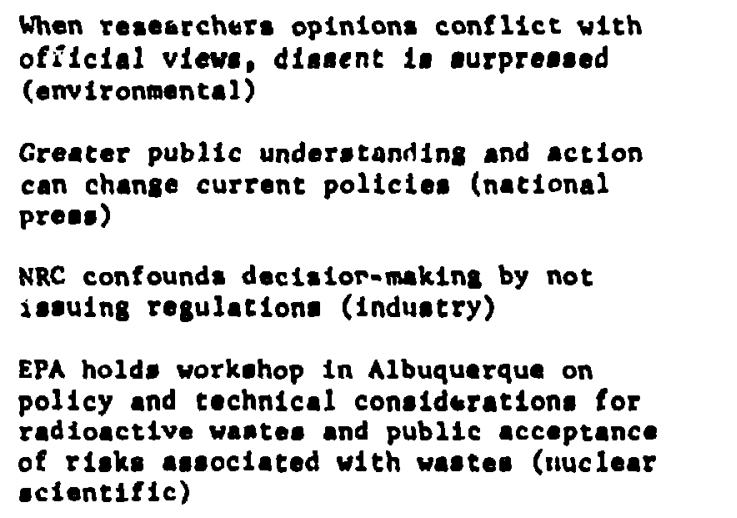 \\
\hline III. Health and Safety Risk & & \\
\hline 9. Transportation & $\begin{array}{l}\text { Descriptions of varlous methods for trans- } \\
\text { porting waste and problems with methods; } \\
\text { reports of transportation accidents, laws. } \\
\text { Initiatives to regulate the tranaporta- } \\
\text { tion of radioactive waste }\end{array}$ & 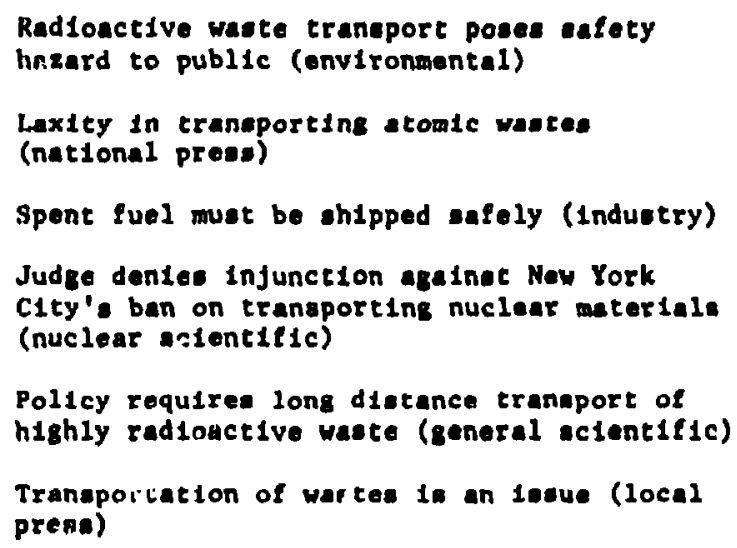 \\
\hline
\end{tabular}


Table 2, Theme categorles (continued)

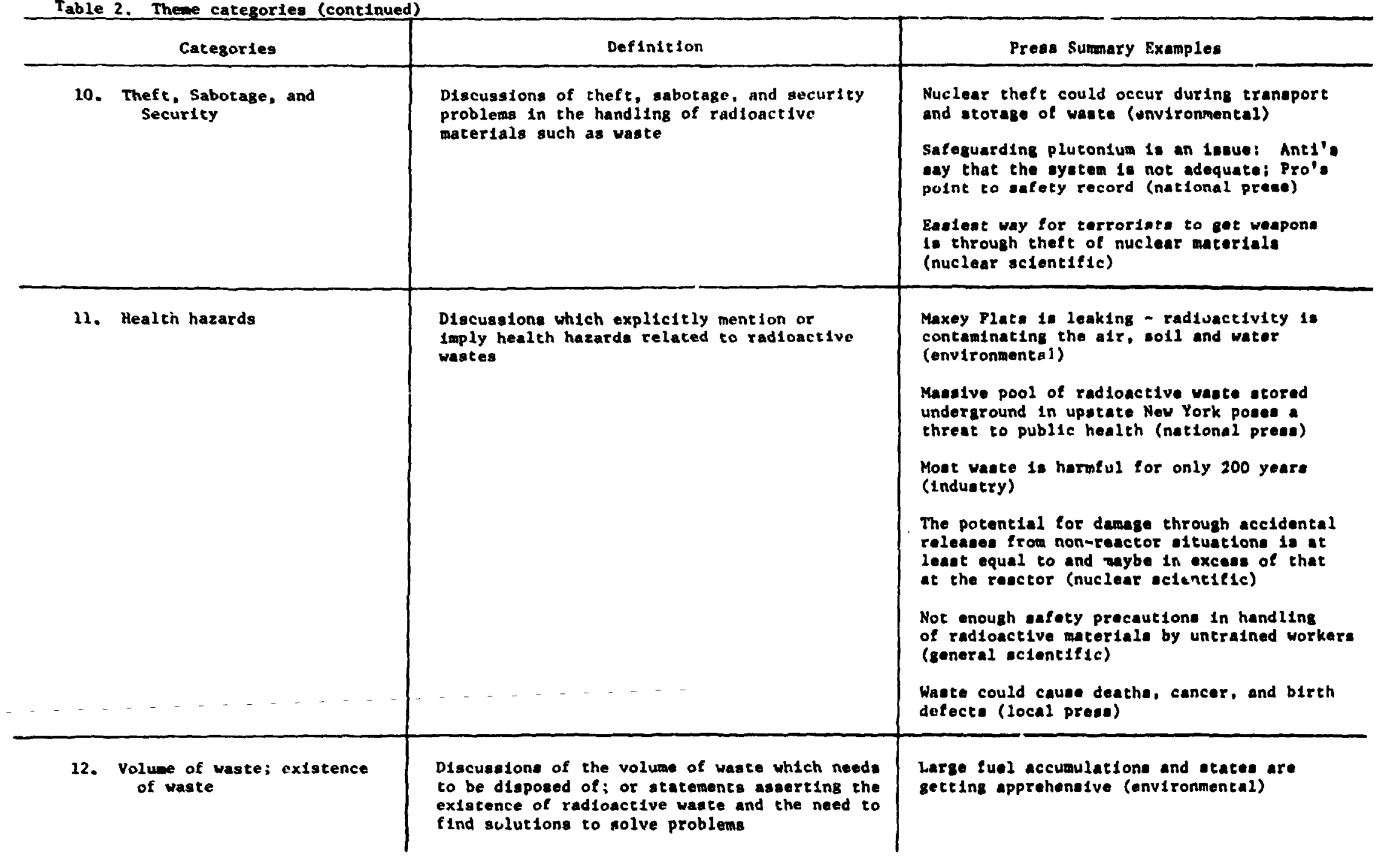


Table 2. Theme cacegorles (continued)

\begin{tabular}{|c|c|c|}
\hline Categories & Defintition & Prese Sumary Examples \\
\hline & & 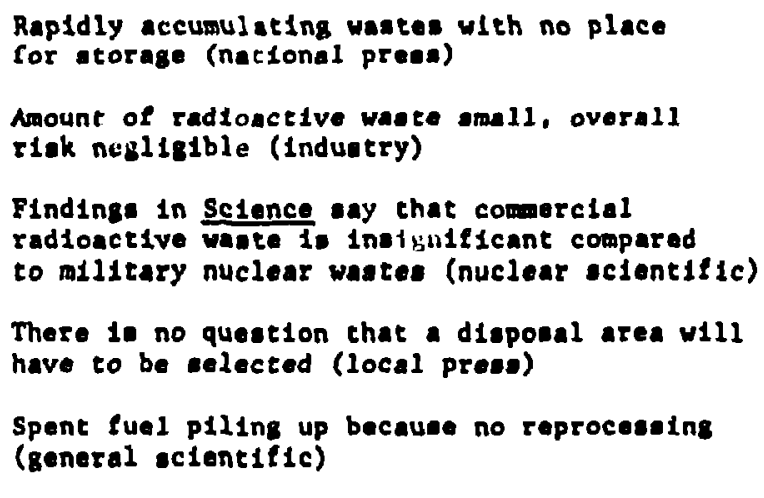 \\
\hline IV. Soc1al/Economic/Ethical Issues & & \\
\hline $\begin{array}{l}\text { 13. Economic costs of waste } \\
\text { management }\end{array}$ & $\begin{array}{l}\text { Discussions of the firancing of waste } \\
\text { management programa, local costs of } \\
\text { giting of butlding or operating } \\
\text { facilities }\end{array}$ & 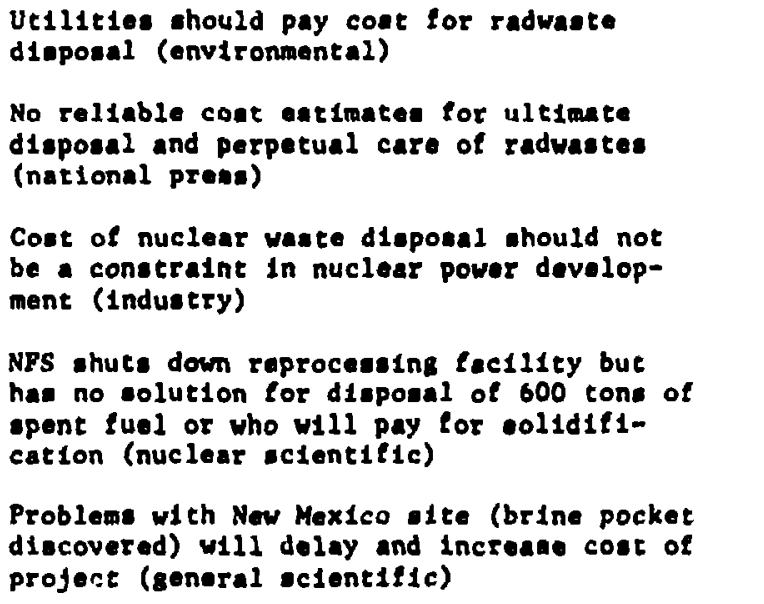 \\
\hline
\end{tabular}


Table 2. Theme categories (continued)

\begin{tabular}{|c|c|c|}
\hline Categories & Definition & Prese Summary Examples \\
\hline & & $\begin{array}{l}\text { Loulalana not committed to radioactive } \\
\text { waste torage unt1l aseured 1t will als } \\
\text { get benefite (e.8. energy or oconomic } \\
\text { activity) (local prese) }\end{array}$ \\
\hline
\end{tabular}

14. Public Reaction
Reports of reactions to specific wasle management policles and actions; and discussions which assert that public opposition is a problem
Barnwell to bufld etorage facility unlese more citizen action (environmental)

Forecast that people at Carlebad, New Mexico will be hospltable to burlal of waste (national prese)

There is a need for local public acceptance of radfoactive waste pollctes (Industry)

C1tizens organization opposes $\mathrm{NY}$ power plant aaying plante are unsafe... and thore is alroady 100 million gallons of wastes and nowhere ro put them (nuclear scientific)

There 1s opposition to storage of atomic wastes In undergrount alt domes (local press)

Si eguarding plutonium would infringe on private rights (exvironmental)

Discussions of the burden to future generations of present radioactive waste pollcles; the potential threats to civil liberties; and the lrreversibility of some nuclear discussions
Safegunida syotem could reault in a garrison atate (nat lonal presa)

Burden on progeny 1s an lesue in radjoactive waste disposal (1ndustry)

Probltm of waste management is more a soc1al. political and ethical challenge (nuclear octentilic)

Probable impact on future generations uncertaln (general oclent1f1c)

Commitment to future generations to deny diaposal of wastes in tate now (lncal government) 
these technologies were "ready," but most of the articies reported successes or failures of existing technology, c: described those that were assumed to be ready. With the exception of some articles found in the nuclear sctentific and general scientific presses, most discussions were quite general and lacking in technical specificity. Technology development issues was the second component of the technical dimension. Discussions were identified as falling in the technology development category if they dealt with experimental results of proposed technologies, discussed the specific research that is needed to make nuclear waste disposal feasible, or identified the general problen of the need for further research.

The management, regulation and institutioual dimension included those thematic categories which discussed the role of different institutions in the policy process or which commented on the development or implementation of polfcies. The "management" category Included discussions of the operation of waste facilities and/or projects, with value judgments regarding the success or failure of the management of these projects. "State and local policfes and decisions" dealt mainly with state/local initiatives in support or opposition to siting waste facilities and were concentrated in the national and locai press sources. The category "Federal governmental policies and decisions" included discussions of the actions at the national level on nuclear waste management. The bulk of these discussions included reports of Federal studies, announcements of policy discussions or of actions to implement policy. "Intergovernmental conflict" themes were those in which the central topic was the existing or potential conflict among various levels or branches of government. The category "International policy and issues" evolved from reports of European experiences in nuclear waste management or of proposals to store International waste in the United States. Themes which dealt with the way in which nuclear waste policies were formulated composed yet another category. The discussions in this category frequently raised the issue of the adequacy of existing arrangements for public input. How these themes were discussed did vary somewhat from one press source to another; In the sclentific sources, the discussions reviewed were in most instances stralghtforward, factual reports, often not accompanied by editorial 
comment. In the environmental sources nearly all of the discussions included in this broad dimension implied that there were problems with existing management or negligence by Federal authorities in dealing with the issue.

Another major underlying dimension of the radioactive waste problem related to the real or perceived health ind safety risk; resulting from the existence, transportation, and handling of nuclear wast.? material. Issues were included in this category if they were explicitly or implicitly concerned with health and safety risks. For example, transiortation issues could be considered technical but were included in this thematic category because the underlying and frequently explicitly stated view was that the transportation of wastes involved risk. Issues in this category ranged from descriptions of methods and reliabilities of transportation to case histories of transportation accidents to state and local inftiatives and laws designed to regulate the transportation of nuclear waste. Likewise, the theme category "volume of waste or the existence of waste" had an underlying concern with the health and safety risks of the continued buildup of waste materials awating final dispostion. Discussions which fell into this category specifically drew attention to the volume of waste which presently needs to be disposed of or will need to be disposed of in the future. These articles were generally critical of current waste management policies, especially with the interim on-site storage regulations. Theft, sabotage and securfty themes were also considered components of the risk dimension. Discussions of risk also varied somewhat from source to source. In the environmental press and the national press the risk discussions were of ten linked to reports of leaks, accidents or to assertions that there is a considerable amount of waste to be disposed of. The scientific sources discussed risk in a relatively objective manner by defining the problem, and by utilizing when appropriate, scientific methods. The nuclear industry/ utility sources discussed risk as a non-issue.

The fourth major underlying dimension dealt with social, economic and ethical themes. The economic costs of waste management programs were one theme category. The financing of a waste management program and local costs of siting, building and operating the facilities comprised the bulk of this category. Public reaction issues formed a second Issue category. Reports of reactions to specific waste management 
policies and actions are included as well as discussions which assert that public opposition is a problem or concern, and should be addressed at some point in the policy process. The final theme dealt generally with ethical issues. This category included the burdens to future generations, the potential threats to civil liberties, and the irreversibility of some nuclear waste policy decisions.

\section{$\underline{\text { Results }}$}

The distribution of issues among the 15 theme categories and summarized for the broad issue categories is presented in Table 3 for each of the specialized and nonspecialized information sources for the 1973-1978 period.

The data indica:ed that for all sources, discussions of radioactive waste have focused more frequently on themes not directly related to the technical problems of radioactive waste storage or isolation.

Information on the activities of different levels of government and of problems related to these activities (e.g., management) makes up from $28.2 \%$ (environmental) to $41.0 \%$ (local press) of the topics discussed in the articles reviewed. In addition, discussions of risks to the public or environment from the existence of the waste, the transporting of wastes or the disposing of wastes receive considerable attention, particularly in the environmental press (39.5\%) as might be expected, and in the national press $(35.7 \%)$. Even in the scientific sources, however, risk themes are discussed relatively frequently: more than technical themes for the general scientific; and slightly less than technical themes for the nuclear scientific sources.

The social, economic and ethical themes as a group receive relatively less attention for all sources with the exception of the local press and the environmental press. Individually, the themes of economic costs and "public reaction" receive a moderate amount of attention relative to the other 13 theme categorles. And in the case of the local press, the number of articles which discuss "public reaction" stands out as a comparatively major theme. Only ethical issues rank low for all sources and relative to the other theme categories. 
Table 3. Percentage distribution of themes by source, 1973-1978

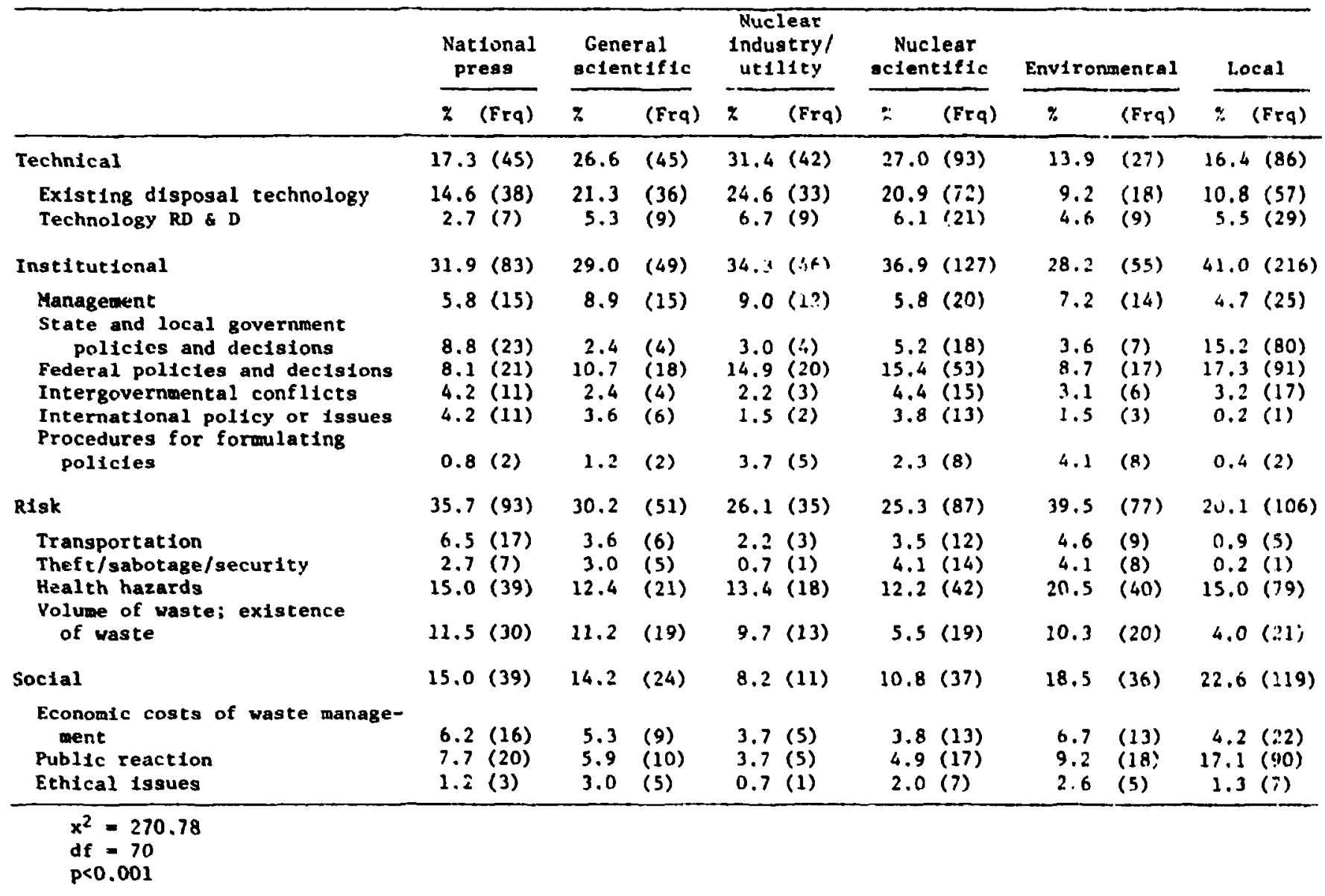


The Dominance of Non-Technical Themes

The distribution of themes among the broad theme categories appears to reinforce the view of many observers that non-technical issues in the debate over radfoactive waste management are as important as, if not more important than, technical issues. What is most interesting from our perspective, however, is that information on the non-technical issues of the problem not only is prevalent in the national press or the environmental press, but also in the general scientific and the nuclear scientific. Certainly this finding suggests that there is a broad spectrum of the public which includes environmentalists, scientists, and "the person on the street" who wil1 identify and define as important a varfety of non-technical issues in the resolution of the radioactive waste problem.

This view is reinforced on closer reading of the individual articles. Discussions in the general scientific and nuclear scientific articles are not simply reports that the lay public is concerned about these issues. They are in uany instances part of a continuing debate within the various journals over specific dimensions of the waste problem.

\section{Risk Themes}

Another expected finding is the relative frequency with which risk themes are discussed. Many students of the nuclear power conflict have asserted that perceived risk is a major factor creating opposition to the

technology. 25 The data in Table 3 provide evidence that a substantial amount of the information available to a variety of segments of the public is composed of discussions of real or percelved risk related to the existence of radioactive waste and the methods for disposing of it. Again, while attention to these themes is found more frequently in the environmental press and the national press, the topic is also discussed frequently in the scientific sources and tie nuclear industry/utility sources.

There are, of course, some differences between the sources in how the risk themes are presented. Reports in the nationa? press, local prese, and the environmental press tend to use provocative language which we suspect reinforces the concept of risk. Moreover, in the environmental and 
national sources, the risk discussions are of ten linked to reports of leaks, accidents or to assertions that there is a considerable amount of waste to be disposed of. The reports of the existence and amount of waste are frequently overstated (e.g., vast quantities of radwaste exist and must be disposed of). The scientific sources discuss the risk problem in a ralatively objective manner by defining the problem, bringing to bear any appropr:ate scientific measures to study the problem and by evaluating the methods and the findings. The tendency of the industry/utility sources is to provide information which denies the importance of the risk dimension in formulating the radioactive waste problem.

\section{Institutional Themes}

The substantial proportion of discussions with institutional themes reflects, we think, the realities of the policy concext. Many governmental jurisdictions and agencies are potentially responsible for or affected by radioactive waste management policies. More importantly, a substantial amount of activity involving these institutions occurred during the period studied: policy alternatives were formally reviewed; a variety of public hearings, including Congressional hearings, were held; the former office of Waste Isolation launched efforts in several states to site a radioactive waste repository; public controversies developed over the responsibility of the State of New York for the decommissioning of the West Valley reprocessIng plant and of the State of Kentucky for the Maxey Flats low level waste facility. 26 That the press would ignore these would appear to be a flagrant abuse of their prerogative to select information to print. The effect of this attention, however, is to advertise the institutional issues or polfcy problems which are inherent in the development and implementation of any policy and to make these 1ssues important in the public's ferception of the prob $1 \% m$.

\section{Socio/Economic and Ethical Themes}

The lack of attention to ethical 1ssues such as the responsibility of this generation to future generations is another interesting finding. These 18sues have captured the Imagination and attention of some scholars who 
address the nuclear waste problem. They may indeed be very important considerations. However, one should not expect many in the attentive public to have thought much about them since so little attention has been giveri to these themes in the different presses.

The data also indicate that in all information sources, public reaction is an important but not a dominant, explicft theme in radioactive waste discussion. While opposition or support may not be explicitly mentioned in individual articles, however, the review of the specific discussion indicates that the existence of controversy is frequently implied. 


\section{PUBLIC INFORMATION OVER TIME ON THE TOPIC OF RADIOACTIVE WASTE}

Has there been a change over time in the content of information on radioactive waste? Have themes emerged and become more or less important as events changed? The data have been divided according to the date of publication into three broad time periods: 1973-74, 1975-76 and 1977-78, which reflect three phases in the current policy debate. During the 1973-74 period radioactive waste was emerging as a policy issue visible to the public. By 1975 and into 1976 there was considerable discussion over the reprocessing of spent fuel as well as referendums in several states over nuclear power and waste 1ssues. By 1977, most of the referendums had been held and President Carter had made his decision to postpone reprocessing.

\section{$\underline{\text { Results }}$}

Tables $4,5,6,7$, and 8 review the distribution of issues for each press excluding local press for the three time periods and Table 9 summarizes these themes for all sources over time. Non-technical issues have for each period, and for each source with the exception of the nuclear scientific, represented a majority of the themes documented in the articles. There has, however, been a shift in the proportions in the theme categories which suggest the emergence and decline of some topics.

National Press - The three time periods suggest general changes in the content of information on radioactive waste (see Table 4). There was a major change in the proportion of institutional themes from $11.5 \%$ in 1973-74 to $40.4 \%$ in 1977-78. Four 18sues emerged during 1975-76 and 197778 to explain this change: "State and Local Policies and Decisions;" "Pederal Policies and Lecisions;" "Intergovernmental Confilcts" and "International Policies or Issues." In 1977-78 these four 1ssues represented 36\% of the total 1ssues analyzed for the sample.

During the six year period there was a decline in the proportion of

"risk" themes from $42.3 \%$ to 33.6\%. "Theft/Sabotage/Security" declined from $7.7 \%$ in $1973-74$ to $0.6 \%$ in 1977-78. "Health Hazards" issues declined 
Table 4. Emergence of themes over time: National Preas

\begin{tabular}{|c|c|c|c|c|c|c|}
\hline & \multicolumn{2}{|c|}{$1973-74$} & \multicolumn{2}{|c|}{$1975-76$} & \multicolumn{2}{|c|}{$1977-78$} \\
\hline & $(\%)$ & $(\mathrm{Frq})$ & $(\%)$ & $\overline{(F r q)}$ & $(\%)$ & (Frq) \\
\hline Technical & 15.4 & (4) & 21.9 & (16) & 15.5 & (25) \\
\hline $\begin{array}{l}\text { Existing disposal technology } \\
\text { Technology RD \& D }\end{array}$ & $\begin{array}{r}15.4 \\
0.0\end{array}$ & $\begin{array}{l}(4) \\
(0)\end{array}$ & $\begin{array}{r}17.8 \\
4.1\end{array}$ & $\begin{array}{l}(13) \\
(3)\end{array}$ & $\begin{array}{r}13.0 \\
2.5\end{array}$ & $\begin{array}{l}(21) \\
(4)\end{array}$ \\
\hline Institutional & 11.5 & $(3)$ & 20.5 & $(15)$ & 40.4 & $(65)$ \\
\hline $\begin{array}{l}\text { Management } \\
\text { State and local government } \\
\text { policles und decisions } \\
\text { Federal policies and decisions } \\
\text { Intergovernmental conflicts } \\
\text { International policy or issues } \\
\text { Procedures for formulating } \\
\text { policies }\end{array}$ & $\begin{array}{l}7.7 \\
0.0 \\
0.0 \\
0.0 \\
0.0 \\
3.8\end{array}$ & $\begin{array}{l}(2) \\
(0) \\
(0) \\
(0) \\
(0) \\
(1)\end{array}$ & $\begin{array}{l}1.4 \\
4.1 \\
0.0 \\
5.5 \\
1.4\end{array}$ & $\begin{array}{l}(1) \\
(3) \\
(0) \\
(4) \\
(1)\end{array}$ & $\begin{array}{r}4.3 \\
13.7 \\
11.2 \\
6.8 \\
4.3 \\
0.0\end{array}$ & $\begin{array}{l}(7) \\
(24 \\
(18) \\
(11) \\
(7) \\
(0)\end{array}$ \\
\hline Risk & 42.3 & (11) & 38.3 & $(28)$ & 33.6 & (54) \\
\hline $\begin{array}{l}\text { Transportation } \\
\text { Theft/sabotage/security } \\
\text { lealth hazards } \\
\text { Volume of waste; existence } \\
\text { of waste }\end{array}$ & $\begin{array}{r}7.7 \\
7.7 \\
19.2 \\
7.7\end{array}$ & $\begin{array}{l}(2) \\
(2) \\
(5) \\
(2)\end{array}$ & $\begin{array}{r}4.1 \\
5.5 \\
21.9 \\
6.8\end{array}$ & $\begin{array}{l}(3) \\
(4) \\
(16) \\
(5)\end{array}$ & $\begin{array}{r}7.5 \\
0.6 \\
11.2 \\
14.3\end{array}$ & $\begin{array}{l}(12) \\
(1) \\
(18) \\
(23)\end{array}$ \\
\hline Social & 30.8 & (8) & 19.2 & $(14)$ & 10.6 & (17) \\
\hline $\begin{array}{l}\text { Economic costs of waste manage- } \\
\text { ment } \\
\text { Public reaction } \\
\text { Ethical issues }\end{array}$ & $\begin{array}{r}11.5 \\
19.2 \\
0.0\end{array}$ & $\begin{array}{l}(3) \\
(5) \\
(0)\end{array}$ & $\begin{array}{l}6.8 \\
8.2 \\
4.1\end{array}$ & $\begin{array}{l}(5) \\
(6) \\
(3)\end{array}$ & $\begin{array}{l}5.0 \\
5.6 \\
0.0\end{array}$ & $\begin{array}{l}(8) \\
(9) \\
(0)\end{array}$ \\
\hline
\end{tabular}


Table 5. Emergence of themes over time: General Scientific

\begin{tabular}{|c|c|c|c|c|c|c|}
\hline & \multicolumn{2}{|c|}{$1973-74$} & \multicolumn{2}{|c|}{$1975-76$} & \multicolumn{2}{|c|}{$1977-78$} \\
\hline & $(x)$ & (Frq) & $(\%)$ & (Frq) & $(\%)$ & (Frq) \\
\hline Technical & 33.4 & (8) & 29.5 & $(10)$ & 24.3 & (27) \\
\hline $\begin{array}{l}\text { Existing disposal technology } \\
\text { Technology RD \& D }\end{array}$ & $\begin{array}{r}29.2 \\
4.2\end{array}$ & $\begin{array}{l}(7) \\
(1)\end{array}$ & $\begin{array}{r}23.5 \\
5.9\end{array}$ & $\begin{array}{l}(8) \\
(2)\end{array}$ & $\begin{array}{r}18.9 \\
5.4\end{array}$ & $\begin{array}{l}(21) \\
(6)\end{array}$ \\
\hline Institutional & 25.0 & (6) & 26.5 & (9) & 30.6 & (34) \\
\hline $\begin{array}{l}\text { Management } \\
\text { State and local government } \\
\text { policies and decisions } \\
\text { Federal polictes and decisions } \\
\text { Intergovernmental conflicts } \\
\text { International policy or issues } \\
\text { Procedures for formulating } \\
\text { policies }\end{array}$ & $\begin{array}{l}16.7 \\
0.0 \\
8.3 \\
0.0 \\
0.0 \\
0.0\end{array}$ & $\begin{array}{l}(4) \\
(0) \\
(2) \\
(0) \\
(0) \\
(0)\end{array}$ & $\begin{array}{l}0.0 \\
8.8 \\
2.9 \\
2.9 \\
2.9\end{array}$ & $\begin{array}{l}(3) \\
(0) \\
(3) \\
(1) \\
(1)\end{array}$ & $\begin{array}{r}7.2 \\
3.6 \\
11.7 \\
2.7 \\
4.5 \\
0.9\end{array}$ & $\begin{array}{l}(8) \\
(4) \\
(13) \\
(3) \\
(5) \\
(1)\end{array}$ \\
\hline Risk & 37.5 & (9) & 32.3 & (11) & 27.9 & (31) \\
\hline $\begin{array}{l}\text { Transportation } \\
\text { Thef } / \text { /sabotage/security } \\
\text { Health hazards } \\
\text { Volume of waste; existence } \\
\text { of waste }\end{array}$ & $\begin{array}{r}8.3 \\
4.2 \\
20.8 \\
4.2\end{array}$ & $\begin{array}{l}(2) \\
(1) \\
(5) \\
(1)\end{array}$ & $\begin{array}{r}2.9 \\
5.9 \\
11.8 \\
11.8\end{array}$ & $\begin{array}{l}(1) \\
(2) \\
(4) \\
(4)\end{array}$ & $\begin{array}{r}2.7 \\
1.8 \\
10.8 \\
12.6\end{array}$ & $\begin{array}{l}(3) \\
(2) \\
(12) \\
(14)\end{array}$ \\
\hline Social & 4.2 & (1) & 11.8 & (4) & 17.1 & (19) \\
\hline $\begin{array}{l}\text { Economic costs of waste manage- } \\
\text { ment } \\
\text { Public reaction } \\
\text { Ethical issues }\end{array}$ & $\begin{array}{l}4.2 \\
0.0 \\
0.0\end{array}$ & $\begin{array}{l}(1) \\
(0) \\
(0)\end{array}$ & $\begin{array}{l}5.9 \\
5.9 \\
0.0\end{array}$ & $\begin{array}{l}(2) \\
(2) \\
(0)\end{array}$ & $\begin{array}{l}5.4 \\
7.2 \\
4.5\end{array}$ & $\begin{array}{l}(6) \\
(8) \\
(5)\end{array}$ \\
\hline
\end{tabular}


Table 6. Emergence of themes over time: Nuclear Sclentific

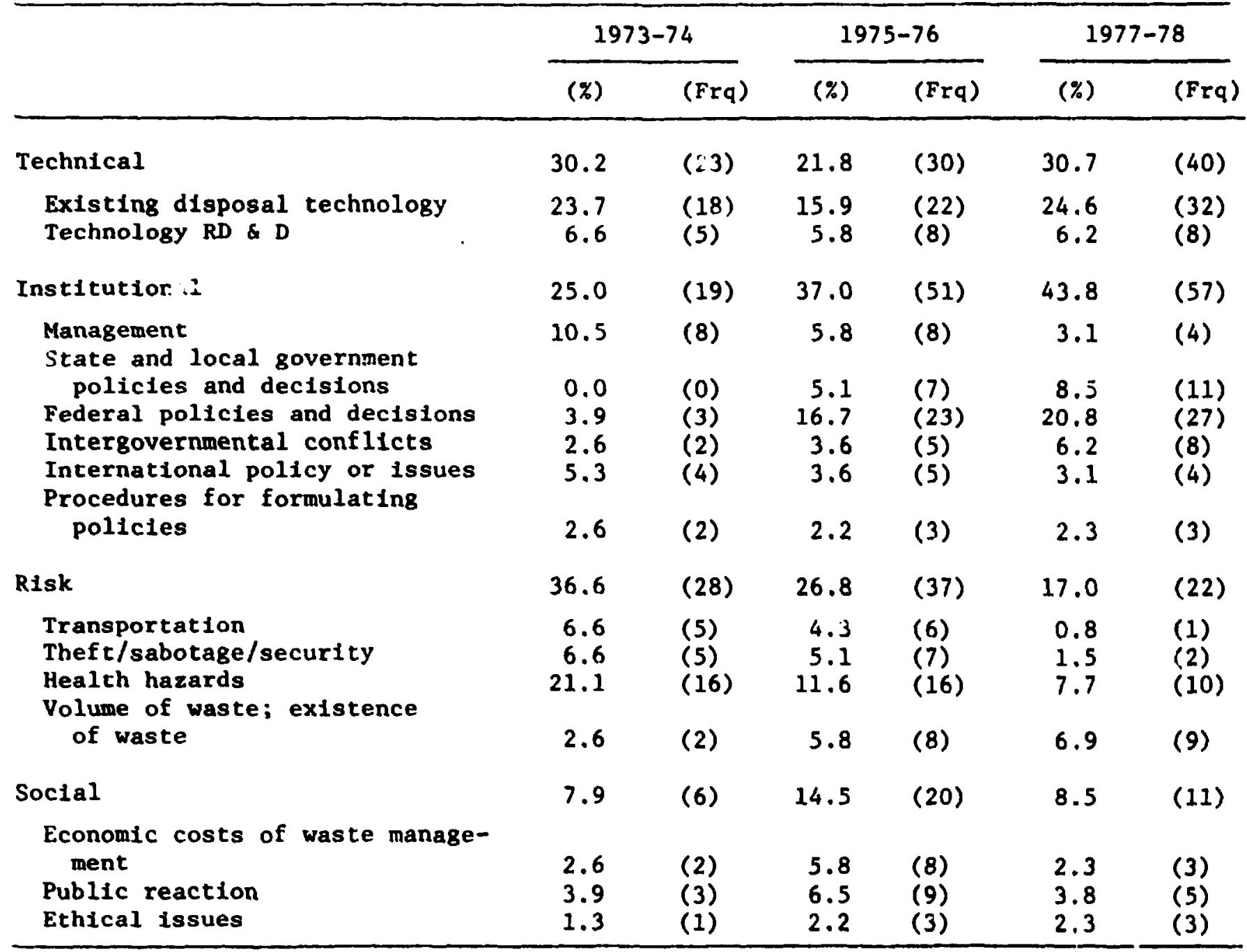


Table 7. Emergence of themes over time: Environmental

\begin{tabular}{|c|c|c|c|c|c|c|}
\hline & \multicolumn{2}{|c|}{$1973-74$} & \multicolumn{2}{|c|}{$1975-76$} & \multicolumn{2}{|c|}{$1977-78$} \\
\hline & $(x)$ & (Frq) & $(z)$ & $(F r q)$ & $(z)$ & (Frq) \\
\hline Technical & 11.1 & (2) & 17.1 & (12) & 12.2 & (13). \\
\hline $\begin{array}{l}\text { Existing disposal technology } \\
\text { Technology RD \& D }\end{array}$ & $\begin{array}{r}11.1 \\
0.0\end{array}$ & $\begin{array}{l}(2) \\
(0)\end{array}$ & $\begin{array}{r}12.9 \\
4.3\end{array}$ & $\begin{array}{l}(9) \\
(3)\end{array}$ & $\begin{array}{l}6.5 \\
5.6\end{array}$ & $\begin{array}{l}(7) \\
(6)\end{array}$ \\
\hline Institutional & 22.2 & (4) & 28.6 & (20) & 29.0 & $(31)$ \\
\hline $\begin{array}{l}\text { Management } \\
\text { State and local government } \\
\text { policies and decisions } \\
\text { Federal policies and decisions } \\
\text { Intergovernmental conflicts } \\
\text { International policy or lssues } \\
\text { Procedures for formulating } \\
\text { pollcies }\end{array}$ & $\begin{array}{l}5.6 \\
0.0 \\
5.6 \\
5.6 \\
5.6 \\
0.0\end{array}$ & $\begin{array}{l}(0) \\
(1) \\
(1) \\
(1) \\
(0)\end{array}$ & $\begin{array}{r}2.9 \\
10.0 \\
0.0 \\
2.9\end{array}$ & $\begin{array}{l}(5) \\
(2) \\
(7) \\
(0) \\
(2)\end{array}$ & $\begin{array}{l}7.5 \\
4.7 \\
8.4 \\
4.7 \\
0.0\end{array}$ & $\begin{array}{l}(8) \\
(5) \\
(9) \\
(5) \\
(0) \\
(4)\end{array}$ \\
\hline Risk & 55.6 & (10) & 37.2 & (26) & 38.3 & (41) \\
\hline $\begin{array}{l}\text { Transportation } \\
\text { Theft/sabotage/security } \\
\text { Health hazards } \\
\text { Volume of waste; existence } \\
\text { of waste }\end{array}$ & $\begin{array}{r}5.6 \\
22.2 \\
22.2 \\
5.6\end{array}$ & $\begin{array}{l}(1) \\
(4) \\
(4) \\
(1)\end{array}$ & $\begin{array}{r}2.9 \\
1.4 \\
25.7 \\
7.1\end{array}$ & $\begin{array}{l}(2) \\
(1) \\
(18) \\
(5)\end{array}$ & $\begin{array}{r}5.6 \\
2.8 \\
16.8 \\
13.1\end{array}$ & $\begin{array}{l}(6) \\
(3) \\
(18) \\
(14)\end{array}$ \\
\hline Soclal & 11.1 & (2) & 17.1 & (12) & 20.6 & (22) \\
\hline $\begin{array}{l}\text { Economic costs of waste manage- } \\
\text { ment } \\
\text { Public reaction } \\
\text { Ethical issues }\end{array}$ & $\begin{array}{l}5.6 \\
0.0 \\
5.6\end{array}$ & $\begin{array}{l}(1) \\
(0) \\
(1)\end{array}$ & $\begin{array}{r}10.0 \\
7.1 \\
0.0\end{array}$ & $\begin{array}{l}(7) \\
(5) \\
(0)\end{array}$ & $\begin{array}{r}4.7 \\
12.1 \\
3.7\end{array}$ & $\begin{array}{l}(5) \\
(13) \\
(4)\end{array}$ \\
\hline
\end{tabular}


Tatle 8. Emergence of themes over time: Nuclear Industry/Ut1lity

\begin{tabular}{|c|c|c|c|c|c|c|}
\hline & \multicolumn{2}{|c|}{$1973-74$} & \multicolumn{2}{|c|}{$1975-76$} & \multicolumn{2}{|c|}{$1977-78$} \\
\hline & $(z)$ & $($ Frq) & $(\%)$ & (Frq) & $(\%)$ & (Frq) \\
\hline Technical & 50.0 & (5) & 24.2 & (15) & 35.5 & $(22)$ \\
\hline $\begin{array}{l}\text { Existing disposal technology } \\
\text { Technology RD \& D }\end{array}$ & $\begin{array}{r}50.0 \\
0.0\end{array}$ & $\begin{array}{l}(5) \\
(0)\end{array}$ & $\begin{array}{r}21.0 \\
3.2\end{array}$ & $\begin{array}{l}(13) \\
(2)\end{array}$ & $\begin{array}{l}24.2 \\
11.3\end{array}$ & $\begin{array}{l}(15) \\
(7)\end{array}$ \\
\hline Inst: tutional & $? 0.0$ & (2) & 40.3 & (25) & 30.6 & (19) \\
\hline $\begin{array}{l}\text { Management } \\
\text { State and local government } \\
\text { policles and decisions } \\
\text { Federal policies and decisions } \\
\text { Intergovernmental conflicts } \\
\text { International policy or issues } \\
\text { Procedures for formulating } \\
\text { policles }\end{array}$ & $\begin{array}{l}20.0 \\
0.0 \\
0.0 \\
0.0 \\
0.0 \\
0.0\end{array}$ & $\begin{array}{l}(2) \\
(0) \\
(0) \\
(0) \\
(0) \\
(0)\end{array}$ & $\begin{array}{r}11.3 \\
0.0 \\
19.4 \\
1.6 \\
1.6 \\
6.5\end{array}$ & $\begin{array}{l}(7) \\
(0) \\
(12) \\
(1) \\
(1) \\
(4)\end{array}$ & $\begin{array}{r}4.8 \\
6.5 \\
12.9 \\
3.2 \\
1.6 \\
1.6\end{array}$ & $\begin{array}{l}\text { (3) } \\
(4) \\
(8) \\
(2) \\
(1) \\
(1)\end{array}$ \\
\hline Risk & 30.0 & (3) & 24.2 & (15) & 26.4 & (17) \\
\hline $\begin{array}{l}\text { Transportation } \\
\text { Theft/sabotage/security } \\
\text { Health hazards } \\
\text { Volume of waste; existence } \\
\text { of waste }\end{array}$ & $\begin{array}{r}20.0 \\
0.0 \\
10.0 \\
0.0\end{array}$ & $\begin{array}{l}(2) \\
(0) \\
(1) \\
(0)\end{array}$ & $\begin{array}{r}0.0 \\
0.0 \\
16.1 \\
8.1\end{array}$ & $\begin{array}{l}(0) \\
(0) \\
(10) \\
(5)\end{array}$ & $\begin{array}{r}1.6 \\
1.6 \\
11.3 \\
12.9\end{array}$ & $\begin{array}{l}(1) \\
(1) \\
(7) \\
(8)\end{array}$ \\
\hline Soctal & 0.0 & $(0)$ & 11.3 & (7) & 6.5 & (4) \\
\hline $\begin{array}{l}\text { Economic costs of waste manage- } \\
\text { ment } \\
\text { Public reaction } \\
\text { Ethical issues }\end{array}$ & $\begin{array}{l}0.0 \\
0.0 \\
0.0\end{array}$ & $\begin{array}{l}(0) \\
(0) \\
(0)\end{array}$ & $\begin{array}{l}4.8 \\
4.8 \\
1.6\end{array}$ & $\begin{array}{l}\text { (3) } \\
\text { (3) } \\
\text { (1) }\end{array}$ & $\begin{array}{l}3.2 \\
3.2 \\
0.0\end{array}$ & $\begin{array}{l}(2) \\
(2) \\
(0)\end{array}$ \\
\hline
\end{tabular}


from 19.27 in 1973-74 to 11.2Z in 1977-78. Only the "Volume/Existence of Waste" category increased from 7.77 in 1973-74 to 14.37 in 1977-78. The transportation category after declining in 1975-76 returned to the proportion it held in 1973-74.

Attention tó social themes also declined substantially particularly with respect to information on public opposition.

General Scientific - The proportion of discussions dealing with technical themes has declined considerably from 33.47 in $1973-i ;$ to 24.37 in 1977-78 (see Table 5). Institutional themes wake up a slightly larger share of the sample in 1977-78 than previous1y, and social themes increased from 4.27 in 1973-74 to 17.17 in 1977-78. "Risix" themes have declined from a high of $37.5 \%$ in $1975-76$ to $27.9 \%$ in $1977-78$.

Several theme categories have emerged: "State and Local Policles and Decisions" and "Values" surfaced in 1977-78. "Intergovernmental Conflict," "Procedures for Formulating Policy," and "Public Reaction" each represent, for the first time, a small percentage in 1975-76.

There was a reduction in the proportion of themes dealing with "Transportation" from 8.3\% in 1973-74 to 2.7\% in 1977-78; and in the "Existing Technology" category from 29.27 in 1973-74 to $18.9 \%$ in 1977-78. The "Health Hazards" category also declined proportlonately over the six year period from $20.8 \%$ to $10.8 \%$. On the other hand, "Volume/Existence of Waste" increased proportionately from $4.2 \%$ in $1973-7$ to $12.6 \%$ in $1977-78$.

The Nuciear Sclentific - As with the two previous press categories, institutional discussions have increased substantially relative to other topics on radioactive waste over the three periods reviewed (see Table 6). kisk themes declined over the three time periods. In contrast with efther the "national press" sources and the "general scientific" sources, most of the 15 themes identified were discussed at least once in the 1973-74 sample. Only discussions of the "State and Local Policies and Decisions" were not incluted in this earlier period, and the "Ethics" category represented only $0.3 \%$ of the sample for the same period. 
A number of themes have, hovever, changed in terms of proportional representation; "Transportation" has changed from 6.67 in 1973-74 to 0.87 in 1977-78; "Management" has declined from 10.52 :o 3.5\%; "Federal Polictes and Decisions" has substantially increased from 3.97 to 20.87 ; "Intergovernmental Conflict" Issues have increased from 2.67 to 6.27; "Theft/Sabotage/ Security" declined from 6.67 to 1.5\%; "Health Hazards" declined from 21.12 to 7.77; and "Volume/Existence of Waste" increased from 2.6\% to 6.97. The "Economic Costs" category, the "Public Reaction" category, and "Existing Techology" category fluctuated during the 1975-76 period but returned to approximately the same proportional representation in 1977-78 as they had in the $1973-74$ period.

Environmental - R'sk themes rank first in frequency discussed for all three time perfod:, although there has been a substantial proportional reduction from the ifrst period (see Table 7 ). This finaing is in contrast to the other three press categories reviewed where efther "Instituctonal" or "technological" themes ranked first. "Social" themes also share a -uch la:-ger proportion of the total sample in each time perind than they do for other sorrces reviewed. Moreover, the discussion of social themes has increased proportionately to $20.6 \%$ over the thriee time periods as the environmental press has focused more on the role of opposition and opposition tactics.

Several themes have emerged after the 1973-74 period. "RD \& D effort" surfaced in the 1975-76 sample, as did "intergovernmental conflicts;" "procedures for formulating policies" and "public reaction." other themes have changed in proportional representation. "Theft/Sabotage/Security" declined as did "Health Hazards." "Volume/Existence of Waste" increased, "Federal Policies anc Decisions" Increased, "International Policies or Issues" declined, "Existing Technology" declined. Other issues showed slight fluctuations during the $1975-76$ period, but remained approx mately the same proportions in the 1973-74 and 1977-78 perfod: economics is one such issue which rose to $10 \%$ in $1975-76$. 
The Nuclear Tndustry/Utility Sources - The sample for the 1973-74 period may be so sra.l that the proportional distributions are misleading and comparison between the three time periods are made difficult (see Table 8;. The size of the sample may reflect, however, a general lack of attention given to radioactive waste issues by industry/utility sources during this period. The sizes of the 1975-76 and 1977-78 sample do permit some comparisons and by 1975-76, there is more information on a broader variety of subjects than in the previous two years. Certainly a variety of additional themes appear to have received attention, 1.e., "Federal Policies and Decisions;" "Procedures for Formulating Policy;" "Volune/Existence of Waste;" and "RD \& D Effort." of these, the "Federal Policies and Decisions" category was proportionately quite high - 19.4\% in the 1975-76 period.

The distribution of issues among the broad categories is quite similar to that observed for other sources by the 1977-78 period, although there are some differences in magnitude. Technical themes at $35.5 \%$ are more represented, followed by institutional themes (30.6\%); risk themes (26.4\%) and social, economic or ethical themes (6.5\%).

The Significance of Changes in the Content of Information

The data suggest for all sources, with the exception of the nuclear Industry/utility, discussions which address the institutional dimensions of the policy problem have increased relative to all other themes and that risk discussions relative to other themes have declined. There is no denying that by $1977-78$ there was relatively more information on institutional dimensions of the waste problem. What the proportions hide over the three time periods is the fact that the total amount of Information avaliable to the public in all dimenstons of the problem has also increased (see Table 9). The significance of this observation is that while relative to other themes the probability that members of the reading public receive Information on risk themes has decreased in 1977-78, overall, the probabilfty that someone would be exposed to a discussion of 
Table 9. Emergence of themes over time/all sources

\begin{tabular}{|c|c|c|c|c|c|c|}
\hline & \multicolumn{2}{|c|}{$1973-74$} & \multicolumn{2}{|c|}{$1975-76$} & \multicolumn{2}{|c|}{ 1977-78. } \\
\hline & $(\%)$ & $(F r q)$ & $(\%)$ & (Frq) & $(\%)$ & $(F r q)$ \\
\hline Technical & 27.3 & (42) & 22 & (83) & 22.3 & (127) \\
\hline $\begin{array}{l}\text { Existing disposal technology } \\
\text { Technology RD \& D }\end{array}$ & $\begin{array}{r}23.4 \\
3.9\end{array}$ & $\begin{array}{l}(36) \\
(6)\end{array}$ & $\begin{array}{r}17.2 \\
4.8\end{array}$ & $\begin{array}{l}(65) \\
(18)\end{array}$ & $\begin{array}{r}16.8 \\
5.4\end{array}$ & $\begin{array}{l}(96) \\
(31)\end{array}$ \\
\hline Institutional & 22.0 & (34) & 32 & $(120)$ & 36 & (206) \\
\hline $\begin{array}{l}\text { Management } \\
\text { State and local government } \\
\text { policies and decisions } \\
\text { Federal policies and decisions } \\
\text { Intergovernmental conflicts } \\
\text { International policy or issues } \\
\text { Procedures for formulating } \\
\text { policies }\end{array}$ & $\begin{array}{l}0.0 \\
3.9 \\
1.9 \\
3.2 \\
1.9\end{array}$ & $\begin{array}{l}(0) \\
(6) \\
(3) \\
(5)\end{array}$ & $\begin{array}{r}2.7 \\
12.7 \\
1.9 \\
3.4\end{array}$ & $\begin{array}{l}(10) \\
(48) \\
(7) \\
(13)\end{array}$ & $\begin{array}{r}8.1 \\
13 . \bar{i} \\
5.1 \\
3.0 \\
1.6\end{array}$ & $\begin{array}{l}(46) \\
(75) \\
(29) \\
(17) \\
(9)\end{array}$ \\
\hline Risk & 39.6 & (61) & 31.1 & (117) & 28.9 & (165) \\
\hline $\begin{array}{l}\text { Transportation } \\
\text { Theft/sabotage/security } \\
\text { Health hazards } \\
\text { Volume of waste; existence } \\
\text { of waste }\end{array}$ & $\begin{array}{r}7.8 \\
7.8 \\
20.1 \\
3.9\end{array}$ & $\begin{array}{l}(12) \\
(12) \\
(31) \\
(6)\end{array}$ & $\begin{array}{r}3.2 \\
3.7 \\
17.1 \\
7.2\end{array}$ & $\begin{array}{l}(12) \\
(14) \\
(64) \\
(27)\end{array}$ & $\begin{array}{r}4.0 \\
1.6 \\
11.4 \\
11.9\end{array}$ & $\begin{array}{l}(23) \\
(9) \\
(65) \\
(68)\end{array}$ \\
\hline Social & 11.0 & (17) & 15.0 & (57) & 13.0 & $(73)$ \\
\hline $\begin{array}{l}\text { Economic costs of waste manage- } \\
\text { ment } \\
\text { Public reaction } \\
\text { Ethical issues }\end{array}$ & $\begin{array}{l}4.5 \\
5.2 \\
1.3\end{array}$ & $\begin{array}{l}(7) \\
(8) \\
(2)\end{array}$ & $\begin{array}{l}6.6 \\
6.6 \\
1.9\end{array}$ & $\begin{array}{l}(25) \\
(25) \\
(7)\end{array}$ & $\begin{array}{l}4.2 \\
6.5 \\
2.1\end{array}$ & $\begin{array}{l}(24) \\
(37) \\
(12)\end{array}$ \\
\hline
\end{tabular}


risk by reading any specialized or general presses has increased. The nuclear scientific press provides the one exception. From 1973-1978, the relative proportion of risk articles declined as well as the absolute number.

The data also suggest that information in the different sources is responsive to changes in policy or in the policy situation. The theft, sabotage, security themes have declined considerably after the postponing of the decision to launch full scale reprocessing of nuclear fuel. The volume/ existence of waste theme received more attention after this decision because spent fuel became identiffed as a waste product. Likewise, the overall increase in attention to institutional issues reflects, as noted before, the increase in institutional activity on the issue. 


\section{COMPARISON BETWEEN SOURCES IN THE CONTENT INFORMATION ON RADIOACT IVE WASTE}

The discussion to this point has focused on the similarities in the content of information on radioactive waste among sources and over time. We now tutn to consider some of the differences between sources which might result in differences within the attentive public in defining the problem of radioactive waste management.

The nuclear industry sources seem least likely of all the presses to provide information on radioactive waste (see Table 8 ). These sources generally have the fewest number of articles and have in the past tended to concentrate upon the technical dimensions of the problem. By 1977-78 the number of articles had substantially increased, suggesting that for those people who rely on these sources for information, the radioactive waste problem is becoming important. Overall, however, the statistics point to a lack of concern with the radwaste problem. From a more subjective view, our reading of the articles also supports this view. The message which emerges from a considerable number of discussions is that radioactive waste is not an important policy issue; that it deserves any attention at all is because it is linked to the problem of putlic acceptance of nuclear power.

The nuclear scientific press has provided considerable information on the topic of radioactive waste. Its attention to the topic was clearly evident in the 1973-74 period and has continued through the 1977-78 perfod (see Table 6). This finding is not unexpected, and suggests that these presses have taken the lead in drawing the public's attention to radwaste issues. In comparison with the other press sources, the nuclear scientific press has been less inclined to discuss the radwaste problem in terms of its risk dimensions. Of all of the press sources, this press was the only one in which both the relative and absolute number of risk themes declined from the 197374 to 1977-78 period. Information on the institutional dimensions of the radwaste problem have, on the other hand, increased substantially, particularly information which focuses on the role of the Federal government. More than all the other sources, and this is substantiated by closer reading of each article, the nuclear scientific press transmits systematically and regularly reasonably objective information on the activities of those 
institutions responsible for or potentially affected by radioactive waste policies. Finally, the nuclear press, not unexpectedly, give more attention than do other presses to the technical dimension of the radwaste problem. This attention has been sustained over the three time periods.

The environmental press is of ten considered, by those closely involved with radinactive waste management, the most deviant of the information sources on radioactive waste. Yet, the statistics demonstrate that in terms of the broad dimensions of the policy discussion this press "tracks" the other wajor sources (see Table 7). The differences which do exist are worth noting, however. Certainly discussions of risk are more prevalent relative to other discussions. Recently this press aiso appears to be giving more attention to discussions of public reaction.

While the environmental press may discuss similar dimensions of the radioactive waste problem is other presses, the information is not always presented in the same manner. Certainly for the environmental press and in comparison with either the nuclear scientific or the general scientific presses, the discussions of waste are more likely to be provocative in tone: the problem of the existence of radioactive waste is "vast;" the issuing of an environmental impact statement is "late;" the health risks potentially affect "millions."

In its early discussions of radioactive waste, the gene:=l scientific press focused on technical issues. While this press does not appear to have initiated much of the information in the different dimensions of the radioactive waste problem, over the years the information presented has touched on the broad spectrum of themes identifled in this study (see Table 5).

The national press discussions of radioactive waste are distinguished from the other presses because of the early attention given to social themes, particularly public opposition. In contrast to other presses, this press also has given approximately equal attention to information on the State and Local Policles and Decisions and to the Pederal Policles and Mecistons. As with the environmental press, information on radioactive waste 18 sometimes presented in a provocative manner. Several headlines from the bibliography suggest the problem: "Riddled with Isotopes;" the "Dead1y Dilemma of Nuclear Wastes;" "A Graveyard for Nuclear Wastes." 
The local press in this study can be distinguished from the other sources because, as noted earlier, the articles used in the study came from newspapers in Louisiana and Michigan In 1976 and 1977. It was during this time that controversies in each state arose over the research activities of the office of Waste Isolation, and the information presented in these articles helped to structure or define for those local citizens the major issues of these controversies. The heavy concentration of discussions which deal with the activities and policies of state government and of dealing with public reaction is different from that which was found for the non-local sources.

These findings are not totally unexpected. The concentration of issues in "public reaction" category and in the "state and local policies" categorles represent certain realities of the situation in both states at that time. Public opposition to the research efforts did develop and was newsworthy. Moreover, state officials, including the governors offices, and the legislatures were actively involved in defining who could legally do what with respect to radioactive waste within the states (the issue of State's Rights quickly emerged) and in finding out what the real intentions of the Federal government were. These offictals in most cases were willing to supply information to the press.

The effect of this publicity, however, may have been to divert the local public's attention from consideration of other dimensions of the controversy. One interesting finding which may temper this conclusion is the large number of articles which were published in each state. The considerable amount of information avallable increased the probability of any dimension of the problem coming to the public's attention. Finally, as with the national press, headlines for the articles were often provocative The frisquency with which the proposed site for a radioactive waste repository was called "dump" is perhaps the most striking example.

In conclusion, different configurations of information and different amounts of information to their constituents over time are apparent, suggesting that groups within the public may emphasize different dimensions of the radioactive waste problem in policy discussions. The most divergent group, we suggest, is the nuclear industry/utility. On the other hand, the dominance of themes which touch on a variety of nontechnical issues for all 
sources point to a broader consensus on the need to address these themes in the policy controversy. 
VII. A NOTE ON THE QUALITY OF TECHNICAL INFORMATION AVAILABLE TO THE PUBLIC

Nuclear waste and its management begins as a technical problem. The technical issues surrounding this problem by themselves require important policy decisions. They are, however, also linked to a variety of social, political, economic and environmental issues. The decision to store spent fuel on an interim basis or to dispose of the spent fuel rods permanently, has, for example, implications not only for the kind of storage techniques to be used but also for the future role of nuclear poser in electricity generation, for the institutional controls necessary for management of the waste and for public acceptance.

As a ronsequence of this relationship, technical information is an important part of understanding the nontechnical issues of nuclear waste management. The study has demonstrated, however, that relative to other dimensions of the policy problem, technical information is provided less frequently. This conclusion is particularly true for the national press, the local press, and the envirnmmental press. Moreover the discussions which we reviewed varied considerably in terms of quality and depth of analysis.

In order to draw some conclusions as to whether the information provided by the different presses facilitates public understanding of the relationships between the basic technical problems of waste management to the variety of nontechnical discussions, we looked at all the articles to determine whether or not they define or distinguish the form (or forms) of waste being discussed (e.g., high level, comercial, low level).

In this study the percentage of articles from all sources which defined the form of radioactive waste being discussed was $50.4 \%$ (see Table 10). Betwean sources, the local press articles stand out as having the smallest proportion (13.2\%) of articles which defined the form of radioactive waste. National press articles also have a comparatively low percentage (45.9\%). The more speciallzed sources are, on the other hand, more likely to define waste: $63.7 \%$ for environmental; $66.5 \%$, nuciear scientific; $75.9 \%$, nuclear industry; $84.3 \%$, general scientific. The finding that the more specialized sources are more likely to define the form of radloactive waste being 
Table 10. Radioactive waste defined by source

\begin{tabular}{|c|c|c|c|c|c|}
\hline & \multicolumn{4}{|c|}{ Define waste } & \multirow{3}{*}{ Total } \\
\hline & \multicolumn{2}{|c|}{ Yes } & \multicolumn{2}{|c|}{ No } & \\
\hline & $(z)$ & (Frq) & $(z)$ & $\overline{(\text { Frq) }}$ & \\
\hline National press & 45.9 & (56) & 54.1 & (66) & 122 \\
\hline General scientific & 84.3 & (59) & 15.7 & (il) & 70 \\
\hline Nuclear scientific & 66.5 & $(145)$ & 33.5 & (73) & 218 \\
\hline $\begin{array}{l}\text { Nuclear industry/ } \\
\text { utility }\end{array}$ & 75.9 & $(60)$ & 24.1 & (19) & 79 \\
\hline Local press & 13.2 & (31) & 86.8 & (204) & 235 \\
\hline Environmental & 63.7 & (65) & 36.3 & (37) & 102 \\
\hline Tota1 & 50.4 & (416) & 49.6 & $(410)$ & 826 \\
\hline
\end{tabular}


discussed is not startling. The relatively small percentage of articles in the non-specialized suurces, however (particularly the small percentage in the local press sources), points out a problem of comminication which potentially affects public understanding of radioactive waste policies. Specifically, many people who rely on these national and local sources for much of their information on specific issues may have little or no basis on which to sort and clarify the diverse technical and nontechnical issues. This lack of information on the basic technical dimensions of the radioactive waste problem can be the basis for a multitude of misperceptions, misunderstandings and conflicts.

of these articles that explain the form or forms of waste being discussed, most of which appear in the more specialized sources, high level waste and high level commercial waste are the most of ten mentioned categories. Combined with the comparatively small proportion of articles mentioning high level military wastes, discussions of some aspect of high level waste occurs approximately $50 \%$ of the time when a form of waste is mentioned.

In addition, since military high level waste makes up a good part of today's waste problem, the apparent lack of frequency with which high level defense waste is explicitly discussed suggests to the authors again that information which clarifies the various dimensions of the radioactive waste problem is not readily avallable to the non-scientific public.

On the other hand, the authors believe it is significant that of those articles in the non-specialized sources that define waste, "high level" waste does not dominate all discussions of the radwaste problem. The frequency with which spent fuel rods are discussed (many of the articles which appeared after the reprocessing decisions) suggests the responsiveness of the various presses to new waste 1ssues. These discussions, coupled with the considerable number of articles which address issues of low level waste, suggest that for the specialized presses, the radwaste problem involves more than high level, commerclal waste. 


\section{FINAL OBSERVATIONS}

It has been over 35 years since the first radioactive waste management policies were implemented and 25 years since the call by scientists for more research and for the revisions of past radioactive waste management policies. 27 Media attention during this period has been sporadic. The issue of radioactive waste appears to have first received major attention during the debates over atmospheric testing. The period from 1973 to 1978 marks, we think, the re-emergence of media attention to the issue.

of what importance to the policy process and to the problem of public acceptance is this attention? This study has explored the effect which this attention may have on how individuals within the public define the policy problem. There are other consequences, however, which deserve some attention. Mazur has suggested that media attention to controversies surrounding policies related to a specific technology tends to focus on the opposition and as a consequence creates more opposition within the public. ${ }^{28}$ While for some sources at certain times public reactions have been given considerable attention relative to other issues (e.g., the National Press in the 1973-74 period, the environmentalists in the 1977-78 period and the local press during specific local controversies), the attention has never appeared to have dominated discussions. Most of the discussions of specific dimensions of the problem implied that there was controversy at least over the particular theme being discussed. Public opposition if it indeed increases as a consequence of media attention, may be as much a result of differences over issues as it is a function of publicity to the opposition.

Another effect of media attention is to increase the audience to the policy process. In the case of radioactive waste, media attention has created a national audience to radioactive waste policy discussions; to efforts at implementing existing waste management policies; and to the fallures and successes of existing management efforts. Moreover, expanding the audience frequently leads to redefining and broadening the scope of the problem and this of ten creates more controversy. 29

Several characteristics with respect to the content of information on radioactive waste suggest that the scope of the problem has been broadened. First, the number of issues related to the general topic on which the public 
is receiving information is considerable. As a consequence the activist, the decision maker, the affected citizen has more opportunity to gain support by appealing to the sentiments or interests of the public on any one of the subissues. Second, if the attention given to the topic of radioactive waste was related exclusively to technical themes, the impact of an expanded audience, we suggest, would be minimal. Most of us would remain uninvolved, allowing the decisions on the technical issues to be made by those more knowledgeable. But the results of this analysis suggest that the discussions of radioactive waste include a wide variety of non-technical issues which are broader in scope. More significantly, non-technical issues have received relatively more attention, specifically "Institutional" and "risk" themes.

Third, the scope of the problem is defined diversely and broadly by the spectrum of information sources. The effect of expanding the scope of the problem is to expand the perceived impact of any decision or policy. As a consequence, new actors become involved and new decision arenas become relevant.

The efforts of OWI to conduct experiments on the suitability of various salt formations for the isolation of high level radioactive waste are, we think, examples of this phenomenon. State politicians, sensitive to the expanded audience to the efforts of the Federal goverment to conduct research, raised issues and questions which they perceived as reflecting the interests of their constituencies and of the national audience. In doing so they frequently redefined the problem and broadened its scope. For example, the safety and health of the local population during the period in whinh the experiments were to be conducted was translated into the question of states' Rights or the risks of nuclear power. In addition, these same politicians, seeking leverage in the decision-making process, introduced the problem in new decision arenas. State legislatures or the governor's office were requested to "take a stand," or to pass legislation. Finally the redefining of issues and expanding the scope of the conflict created more publicity which was then translated into "new information" on radioactive waste. The 
results of this process were frequently frustrating to the policy-makers. What was thought of as a relatively simple policy task erupted into a complex and sometimes embarrassing controversy.

The above discussion suggests how the availability of public information on a policy topic compounds the task of defining and implementing policies. Public information is only one of a number of democratic practices, however, which makes policy making complicated. Comitted to public involvement, the Federal government chooses to work with the States or a public utility like TVA to implement radioactive waste policies. This commitment also introduces new actors, raises new issues and generally confounds the resolution of the problem.

Lest one forget the obvious, expanding the autience to a debate, redefining the policy problem, introducing new actors, or shifting decision arenas can be beneficial steps in the evolution of a major policy. Certain$1 y$ in radioactive waste this would appear to be the case. In the past 20 years, there has been considerable controversy between some members of the scientific community and federal bureaucrats over the direction of radioactive waste research and the form of radioactive waste management policies. These controversies have revolved around a variety of technical issues. As controversies and decisions however, came increasingly under public scrutiny, new issues emerged reflecting broader social concerns. These new issues and the expanded audience to the policy discussions have frequently frustrated the decision-maker and made resolution of policy decisions more difficult. They have, at the same time, resulted in new efforts by scientists and bureaucrats to rethink the original technical problems, and have contributed to redefining the scope of the radioactive waste policy problem to include all forms of radioactive waste, as well as a variety of nontechnical concerns. They have resulted in new policies which, in the opinion of the authors, more accurately reflect the realities of the nuclear industry.

Finally, the focus of this study has been on the information available to the general public on the topic of radioactive waste. It described the kinds of topics that gain media attention over time and what types of sources focus on what kinds of 18sues. While not a measure of public opinion, the study has been a measure of the emergence of issues in public 
printed discussions oi radioactive waste. As such, it suggested those aspects of the policy problem on which the public may focus in the formation of public opinion. The study is limited, however, in that it does not describe the intensity or the direction (pro or con) of the issues. In addition, the study is not a measure of the importance of issues, a priori. Those issues which receive the most coverage in printed discussions relative to other issues may or may not deserve the most attention in the development of a responsible public policy. How important the issues are as defined by the printed sources depends to a great extent on the judgment of the policy analyst. He must determine if those issues which are discussed most frequently in the printed press reflect major dimensions of the polfcy problem. 


\section{REFERENCES}

1. The Executive Office of the President, Energy Policy and Planning, the National Energy Plan, April 29, 1977.

2. Memorandum from the President of the United States, Jimmy Carter, The white House, March 13, 1978.

3. Report to the President by the Interagency Group on Nuclear Waste Monagement, Draft, October 1978, Washington, D.C., 710-28\&,17, Appendix C.

4. Kodger Cobb et al., "Agenda Building as a Comparative Political Process," American Political Science Review, Vol. .0, 1976, pp. 126-138.

5. Dan Nimmo, Political Commmication and Public Opinion in America, Goodyear Publishing Co., Santa Monica, California, 1978, pp. 224-45;

Joseph T. Klapper, The Effects of Mass Communication, Freepress, Glencoe, Illinois, 1960.

6. There is some evidence which suggests that an inczease in media coverage increases opposition to technological innovations in which there is controversy. See A. Mazur, "The Rise and Fall of Protest Activity Against Four Technologies," The American Sociological Association Convention, San Francisco, September 14-18, 1978. This point will be addressed at the end of the paper.

7. Dan Nimmo, op cit.

8. V. 0. Key first distinguished between the mass public and the attentive public. The latter group are individuals who are aware of and seek out information on specific public issues. Others have refined Key's distinctions to include the notion of interest publics.

9. Dorothy Nelkin describes a variety of interests in her analysis of the nuclear power controversy at Cayuga Lake in upstate New York. These include: some nuclear experts; the ulilities; a group of concerned scientists; the concerned public and official government bodies. Her study, as well as our own intuitive understanding of the key interests suggested the major source categories. See Dorothy Nelkin: Nuilear Power and Its Critics, Ithacá, Cornel]. University Press, 1971.

10. Content analysis is a method of studying and analyzing communications in a systematic, object've and quantitative manner for purposes of measuring variables. F. N. Kerlinger, Foundations of Behavional Research, New York: Holt, Rinehart, Inc., 1966, pp. 544-553.

11. "77 Ayer Directory of Publications," Ayer Press, Philadelphia, 1977.

12. Ibid.

13. Ibid. 
14. Personal communication with Critical Mass Circulation Office, Washington, D.C.

15. Personal communication with Tom Turner, Friends of the Earth.

16. The index of agreement measures the proportion of articles in which the same themes or topics were mentioned by two separate coders. Each coder was allowed to list as many themes as necessary to summarize the article. If those themes were also identifled by the second coder, the coders were considered to agree.

17. Public opinion surveys indicate that until late 1974 nuclear waste did not seem to be an important enough issue to freely come to the minds of survey respondents. From 1974 to 1978, however, there has been growing public concern. See Barbara D. Melber, Nuclear Power and the Public: Analysis of Collected Survey Research, Battelle Memorial Institute, HARC, Seattle, Washington, November 1977.

18. Clay Schoenfeld, "The Changing Role of Mass Communication in Environmental Education," The Journal of Environmental Education, Vol. 8, Spring, 1977. Schoenfeld discusses the role specialized journals have played in drawing the attention of the mass media and as a consequence, of the public, to specific issues. He calls this the "agenda setting" function. He concludes by observing that today the agenda setting function of the media - at least for environmental issues - is diffised and inclusive of the mass media.

19. NAS/NRC Report: The Disposal of Radioactive Waste on Land, September 1957.

20. See Skip Laitner, Citizen's Guide to Nuclear Power, Center for the Study of Responsive Law, 1975 and A. M. Weinberg, "Social Institutions and Nuclear Energy," Science, July 7, 1972, pp. 27-34.

21. Nuclear Reactors Built, Being Built or Planned in the United States, June 30, 1970-December 31, 1974, U.S. Atomic Energy Commission, Division of Technical Information.

22. J. Fred Springer and Edmond Costantini, "Public Opinion and the Environment: An Issue in Search of a Home," in Environmental Politics, ed. Stuart S. Nage1, Praeger, New York: 1976, p. 207. The authors clte numerous references which through content analysis have demonstrated Increased media attention to environmental 1ssues between 1960 and 1973.

23. Anthony Downs, "Up and Down with Ecology - the 'Issue-Attention Cycle,'" The Public Interest, Vo1. 28, Summer 1972, pp. 38-50. 
24. Interestingly, a recent report prepared by J. A. Hébert et al., and entitled The Nontechnical Issues in Waste Management: Ethical, Institutional and Political Concerns (PNL-2400, Battelle, HARC, May 1978) lists 13 nontechnical issues in radioactive waste management. Many of these issues are the same as those which emerged from our analysis.

25. See for example Paul Slovic, B. Fischoff, S. Lichtenstein and C. Hohenemser, "Perceived Risk," Environment, 1979 (In press); Paul Slovic, S. Lichtenstein and B. Gischoff, "Images of Disaster: Perception and Acceptance of Risks from Nuclear Power," Proceedings of the Second International Scientific Form on an Acceptable World Energy Future. A. Perlmutter et al., eds., Cambridge, Massachusetts: Ballinger, 1979; L. Ross, "The Intuitive Psychologist and His Shortcomings: Distortions in the Attributive Process," In L. Belkowitz et al., Advances in Experimental Social Psychology, New York:

Academic Press, 1977, pp. 173-220, and Chauncey Starr, "Social Benefit versus Technological Risk," Science, 1969, PP. 165, 1232-1238.

26. No systematic review of all the activities related to radioactive waste management exists. For one history of radioactive waste management policy see Daniel S. Metlay, "History and Interpretation of Radioactive Waste Management in the United States," in W. P. Bishop et a:., Essays on Issues Relevant to the Regulation of Radioactive Waste Management, NUREG-0412, May 1978.

27. NAS/NRC Report, op cit.

28. A. Mazur, op cit.

29. The notion of broadening the scope of the problem and expanding the audience to a policy discussion comes from E. E. Schattsneider, The Semi-So,ereign People, New York: Holt, Rinehart and Winston, 1960. 
ORNL/UIAPA-13

\section{INTERNAL DISTRIBUTION}

$\begin{array}{ll}\text { 1. S. I Auerbach } \\ \text { 2. } & \text { L. G. Berry } \\ \text { 3. } & \text { R. B. Braid } \\ \text { 4-28. } & \text { B. H. Bronfman } \\ \text { 29-53. } & \text { L. M. Bronfman } \\ \text { 54. } & \text { S. A. Carnes } \\ \text { 55. } & \text { R. S. Carlsmith } \\ \text { 56. } & \text { E. D. Copenhaver } \\ \text { 57. } & \text { K. E. Cowser } \\ \text { 58. } & \text { R. M. Davis } \\ \text { 59. R. C. DeVault } \\ \text { 60. W. Fulkerson } \\ \text { 61. R. B. Honea } \\ \text { 62. S. V. Kaye } \\ \text { 63. C. A. Little }\end{array}$

\author{
64. E. G. Llewcllyn \\ 65-74. D. C. Parzyck \\ 75. E. B. Peelle \\ 76. A. S. Quist \\ 77. M. Schweitzer \\ 78. J. W. Sims \\ 79. W. G. Stockdale \\ 80. A. H. Voelker \\ 81. T. J. Wilbanks \\ 82-83. Central Research Library \\ 84. Y-12 Technical Library \\ 85-89. Laboratory Records \\ 90. Laboratory Records (RC) \\ 91. ORNL Patent office
}

\section{EXTERNAL DISTRIBUTION}

92. Office of Assistant Manager, Energy Research and Development, Department of Energy, Oak Ridge Operations Office, Oak Ridge, TN 37830

93-119. Technical Information Center, P.0. Box 62, Oak Ridge, TN 37830

120. P. J. Bankston, office of Science and Technology, 1307 Woolfolk office Building, Jackson, MS 39202

121. C. C. Burwe11, Oak Ridge Associated Universities, Institute for Energy Analysis, P.0. Box 117, Oak Ridge, TN 37830

122. J. Tadlock Cowan, Bullding A, Apt. 2, 715 Triphammer Road, Ithaca, NY 14850

123. Brooke Deaner, Water Quality Commission, West Virginia Department of Natural Resources, 699 State office Bullding 3, 1800 Washington St. E, Charleston, WV 25305

124. William DeVille, Governor's Office of Science, Technology and Envirommental Policy, P.0. Box 44066, Baton Rouge, LA 70804

125. Ms. Cherry Duckett, Arkansas Energy Conservation and Policy Office, 960 Plaza West B1dg., Little Rock, AR 72205

126. Brian Flattery, Energy Division, North Carolina Dept. of Commerce, 430 N. Salisbury Street, Raleigh, NC 27611

127. Paul G. Gosselink, Supreme Court Building, P.0. Box 12548, Austin, TX 78711

128. Damon Harrison, Department of Energy, Capitol Plaza Tower, Frankfort, kY 40601

129. J. A. Hébert, Battelle Human Affairs Research Center, Seattle, WA 98105 
130. Jeff Herholdt, Jr., West Virginia Fuel and Energy office, 12611 1/2 Greenbrier St. Charleston, wV 25311

131. Norman Hilberry, Department of Nuclear Engineering, University of Arizona, Phoenix, AZ 85721

132. Richard Hill, Oklahoma Department of Energy, $4400 \mathrm{~N}$. Lincoln Blvd., Suite 251, Oklahoma City, OK 73105

133. Milton Holloway, Texas Energy Advisory Council, 7703 North Lamar, Austin, TX 78752

134. Edwin Hudspeth, Alabama Development Office, State Capitol, Montgomery, AL 36130

135. Interagency Review Group on Nuclear Waste Management, Room 8137, 20 Massachusetts Ave., NW, Washington, DC 20545

136. Shelby Jett, Capitol Plaza Tower, Frankfort, KY 40601

137. Tom C. Landrum, Louisiana Department of Natural Resources, P.0. Box 44156, Baton Rouge, LA 70804

138 Daniel S. Metlay, Department of Political Science, Indiana University, Bloomington, IN 47401

139. Robert C. Mitchell, Resources for the Future, 1755 Massachusetts Avenue Nw, Washington, DC 20036

140. Robert L. Morgan, Of fice of Waste Isolation, U.S. Department of Energy, Washington, DC 20545

141. G. Oertal, Divistion of Waste Products, office of Nuclear Waste Management, U.S. Department of Energy, Mail Station D-107, Washington, DC 20545

142. Hamilton Oven, Florida Department of Enviromental Regulation, Twin Towers office Building, 2600 Blair Stone Road, Tallahassee, FL 32301

143. Dr. Lamar Priester, Jr., South Carolina Office of Energy Resources, Edgar A. Brown Building, 1205 Pendleton Street, Columbia, Si 29201

144. Bernard J. Schroer, P.0. Box 1247, Huntsville, AL 35807

145. James L. Setser, 270 Washington Street, NW, Atlanta, GA 30334

146. Dr. Paul Slovic, Decision Research, 1201 Oak Street, Eugene, OR 97401

147. Jarrel1 Southal1, 8001 National Drive, P.0. Box 9583, Little Rock, AR 72219

148. Boyd Spencer, Virginia State Energy office, 823 E. Main Street, Richmond, VA 23219

149. Ed Spitzer, Tennessee Energy Authorit), 250 Capitol Hill Building, Nashville, TN 37219

150. Denver Ta1ley, Department of Pollution Contro1, Box 53504, NE 10th and Stonewall, Oklahoma City, OK 73105

151. Reginald Wallace, Virginia Council on Environment, 903 9th Street Office Bullding, Richmond, VA 23219

152. P. J. Walley, 1307 Woolfolk office Building, Jackson, MS 39202

153. Dr. Carlos Warren, Florida Department of Enviromental Regulation, 2600 Blair Stone Road, Tallahassee, FL 32301

154. Robert Wolle, 329 Corde1l Hull Building, 436 6th Ave. North, Nashville, TN 37219

155. Glen Wool, Jr., Mississippi Air and Water Pollution Control Commission, Robert E. Lee Building, Jackson, MS 39201

156. Mark Zwecker, Georgia State Energy office, 270 Washington Street, NW Atlanta, GA 30334 